\title{
Attenuation and excision of a crustal section during extensional exhumation: the Carratraca Massif, Betic Cordillera, southern Spain
}

\author{
T. W. ARGLES ${ }^{1}$, J. P. PLATT ${ }^{2}$ \& D. J. WATERS ${ }^{3}$ \\ ${ }^{1}$ Department of Earth Sciences, The Open University, Walton Hall, Milton Keynes MK7 6AA, UK \\ (e-mail: t.w.argles@open.ac.uk) \\ ${ }^{2}$ Department of Geological Sciences, University College London, Gower Street, London WC1E 6BT, UK \\ ${ }^{3}$ Department of Earth Sciences, Parks Road, University of Oxford, Oxford OX1 3PR, UK
}

\begin{abstract}
Extensional dismemberment of the Betic Cordillera during Late Oligocene to Early Miocene time caused attenuation and excision of a crustal section overlying mantle peridotite. An integrated study of metapelites overlying the peridotite sheet in the Carratraca area shows truncation of a typical orogenic cycle of burial and heating by rapid exhumation and late- to post-tectonic, low-pressure metamorphism. Attenuation by a factor of five or more condensed a greenschist to granulite section to $4 \mathrm{~km}$ structural thickness.

Initially coaxial attenuation of the sequence, involving formation of a flat-lying foliation and conjugate shear bands, was superseded by non-coaxial deformation concentrated along low-angle, top-to-the-NE, extensional fault zones. These excised parts of the metamorphic section; a $2 \mathrm{~km}$ loss was calculated across one fault zone.

Thermobarometry throughout this section demonstrates that the structural attenuation was related to isothermal decompression to low pressures $(2-4 \mathrm{kbar})$ even at the base of the crustal section. A late thermal event largely postdates the ductile stage of attenuation, particularly in the upper part of the section. Thermal modelling implies that this thermal event could not have been produced by the hot peridotite sheet alone. Rapid tectonic exhumation and asthenospheric upwelling are the probable causes, following detachment of material from the base of the lithosphere.
\end{abstract}

Keywords: Betic, Cordillera, extension, decompression, exhumation, polymetamorphism.

In recent years it has become apparent that many compressional mountain belts have undergone large amounts of vertical thinning at late stages in their evolution, resulting in the exhumation of rocks from deep in the crustal section (Dewey 1988). In the Betic Cordillera of Southern Spain (Fig. 1) this process has even resulted in the exposure of large bodies of sub-continental lithospheric mantle peridotite at the surface (Vissers et al. 1995), and the subsidence of large parts of the orogen below sea-level (Platt \& Vissers 1989). The causes of this late orogenic extension remain controversial, but a key factor is likely to be the behaviour of the lithospheric mantle beneath the orogen (Houseman 1996, and references therein). Recent models include slab rollback (Royden 1993), slab detachment (Wortel \& Spakman 1992), delamination (Channell \& Mareschal 1989), and convective removal of lithosphere (England \& Houseman 1989; Platt \& England 1994). These models have significant and different implications for the thermal structure of the crust and lithosphere, and the way that thermal structure will evolve during extension. The pressure-temperature-time $(P-T-t)$ evolution of the crust is therefore crucial to testing of these ideas. The purpose of this paper is to present an integrated structural and metamorphic study of a section in the western part of the Betic Cordillera that extends from upper crustal rocks down to the contact with exhumed mantle peridotite. The evolution of this crustal section is examined in the context of the Alpine Orogeny, with constraints from $P-T$ determinations on samples representing a range of structural depths. These data are compared with simple models predicting the thermal evolution of the lithosphere for various tectonic scenarios. The resultant picture is one of rapid exhumation and attenuation of mid-crustal rocks following removal of material from the base of the lithosphere. We suggest that the thermal regime of the crustal section was dominated by upwelling asthenosphere and advective heat transfer, rather than the emplacement of a hot peridotite slab into the crustal gneisses as suggested previously (Loomis 1972a, b; Westerhof 1977; Torres-Roldán 1981).

\section{Regional geology}

The Betic Cordillera forms the northern part of the tightly arcuate Betic-Rif orogenic belt (Fig. 1), the Internal Zones of which were formed by late Mesozoic-Neogene convergence between Africa and Eurasia (Dewey et al. 1989). The arc encloses the Alboran Basin, a region of high heat flow underlain by thin $(15-20 \mathrm{~km})$ continental crust (Torné \& Banda 1992), with up to $7 \mathrm{~km}$ of post-early Miocene marine sediment fill (Comas et al. 1992; Morley 1993), interpreted as a site of early Miocene extension (Watts et al. 1993). The Betic orogen is composed of a metamorphic core (Internal or Betic Zone), with an extensive Neogene fold-and-thrust belt of unmetamorphosed Mesozoic cover (External or Subbetic and Prebetic Zones) to the north. The Betic Zone appears to have been formed as a thrust stack of Palaeozoic, Mesozoic and locally Palaeogene sediments, probably during Late Cretaceous to Palaeogene time. The uppermost thrust slices (Malaguide) show little or no metamorphism; the remainder show evidence of early medium to high pressure metamorphism, locally reaching blueschist and eclogite facies (De Roever \& Nijhuis 1964; Gomez-Pugnaire \& Fernandez-Soler 1987; Bakker et al. 1989; Tubía \& Gil Ibarguchi 1991). Evidence for early metamorphic pressures of 7-10 kbar in lower grade rocks, based on 


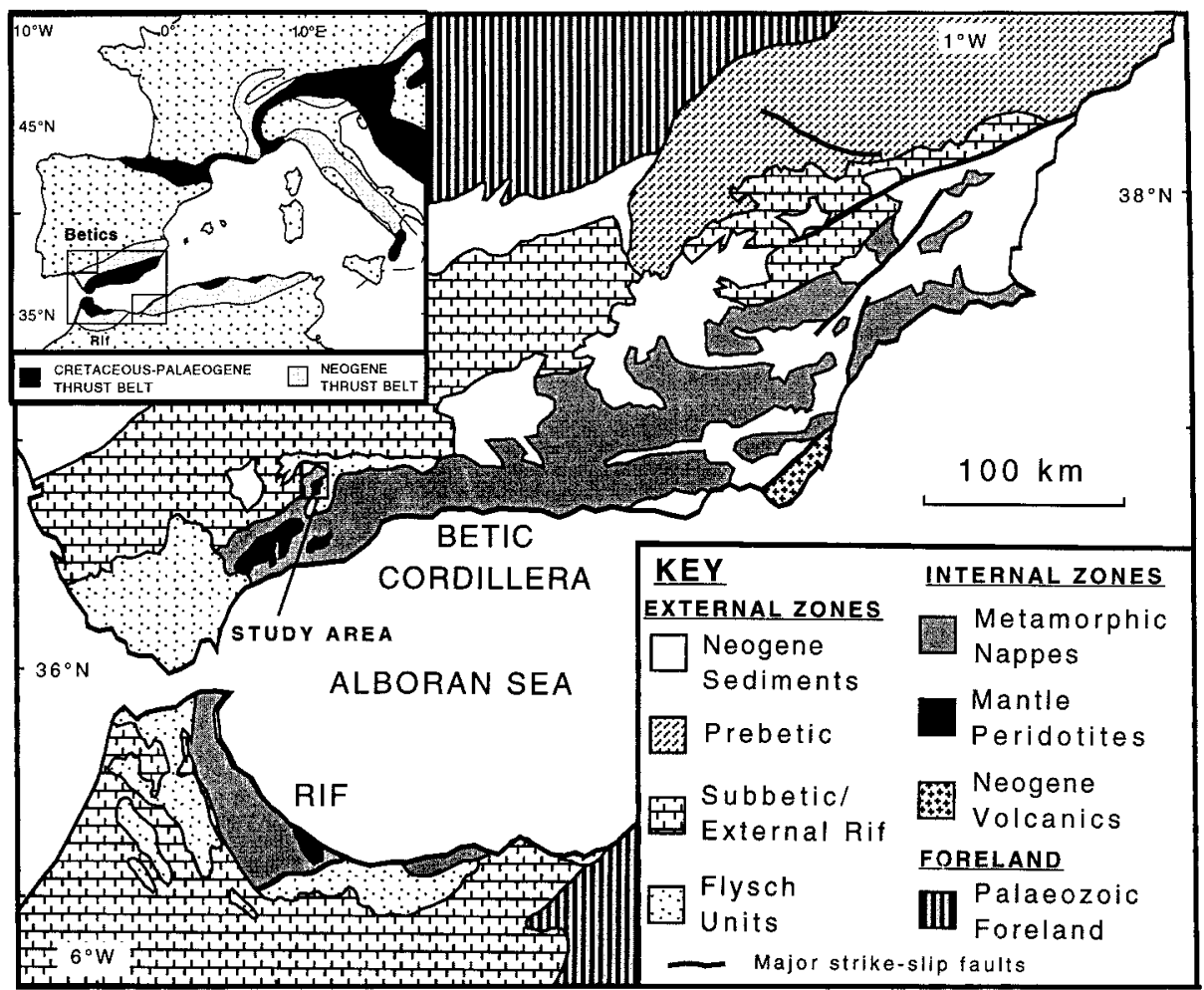

Fig. 1. Simplified geology of the Betic-Rif Arc in the context of the Alpine orogenic belts in the western Mediterranean region, showing the Ronda peridotite bodies in black. vein assemblages including carpholite, has been presented by Goffé et al. (1989) and Azañon \& Goffé (1997), while peak pressures of $14-15 \mathrm{kbar}$ are obtained from mafic granulites adjacent to the peridotite sheets (Tubía 1994; this study). Metamorphic grade locally reaches upper amphibolite and even granulite facies, particularly in the vicinity of peridotite sheets in the Ronda region (Fig. 1), which were emplaced into the Betic crust from the mantle. Short-wavelength positive gravity anomalies associated with these sheets (Torné \& Banda 1992) are interpreted as representing a subsurface, $8 \mathrm{~km}$ thick peridotite slab dipping SSE (Torné et al. 1992).

The study area is centred on the village of Carratraca, $40 \mathrm{~km}$ WNW of Málaga, and dominated by the two smallest outcrops of the Ronda Peridotite group (Figs 1 \& 2). These probably originally continuous bodies are overlain by the crustal metapelites of the Los Reales nappe, divided for the purposes of this study into a number of distinct zones (see Table 1 below, and Fig. 2). Zone boundaries are essentially based on metamorphic criteria (Table 1), but most coincide with tectonic discontinuities. This accentuates the differences between them, since gradual metamorphic transitions are condensed or truncated entirely at these boundaries.

The Alpujarride section lacks the uppermost Triassic carbonates seen elsewhere (e.g. Balanyá et al. 1993), due to excision at the top contact. Overlying this contact is a disrupted section of Malaguide rocks. Locally, thin slivers of phyllites of intermediate grade between the two complexes occur along the contact. The crustal metapelites of the Los Reales nappe generally dip away from the peridotite coring this local culmination (Fig. 3). Overlying large areas of the Internal Zone rocks along an irregular, subhorizontal contact are the so-called 'Flysch Units', a complex group of mélanges probably of early Miocene age. Later Miocene (Tortonian) clastic sediments transgress locally over all rock types, and are horizontally bedded.
This study focuses on the structural and metamorphic characteristics of the crustal section of the Los Reales nappe, a sequence of graphitic Palaeozoic metapelites with overlying graphite-poor Permo-Triassic metapelites and metapsammites, known as the Jubrique Unit (Balanyá 1991). The unit has a structural thickness of $3-4 \mathrm{~km}$ in the study area (up to $5 \mathrm{~km}$ regionally; Balanyá 1991; Balanyá et al. 1993), with strongly condensed isograds: metamorphic grade increases from greenschist facies at the upper contact with the Malaguide to granulite facies in contact with the peridotite at the base. In addition to this extreme apparent thermal gradient, the whole section experienced a late- to post-tectonic heating event during marked decompression (Argles 1996).

\section{Structural/kinematic evolution of the Jubrique Unit}

\section{Early planar fabrics}

At least one planar tectonic fabric predates the main foliation in the Jubrique Unit. Meso-scale folds related to the formation of the main foliation (referred to as S3) clearly fold a preexisting differentiated tectonic fabric (S2), and this is abundantly confirmed in thin section, where many porphyroblasts contain included fabrics at various stages of the crenulation process forming S3. Some examples of these included fabrics (S2) appear to be crenulations themselves, possibly of an earlier, bedding-parallel schistosity (S1/S0). Inclusion fabrics (in $\mathrm{Ky}, \mathrm{St}, \mathrm{Pl}$, And) are defined by fine-grained graphite, with micas, quartz and accessories; some porphyroblasts $(\mathrm{Pl}, \mathrm{St})$ also enclose small garnet and kyanite crystals. Extreme transposition of the lithological layering during S3 formation obscures its relationship to S2. However, the association of the $\mathrm{S} 2$ inclusion trails with early mineral growth (e.g. Grt, Ky) implies that it formed during a prograde burial stage related to crustal thickening and horizontal compression. 


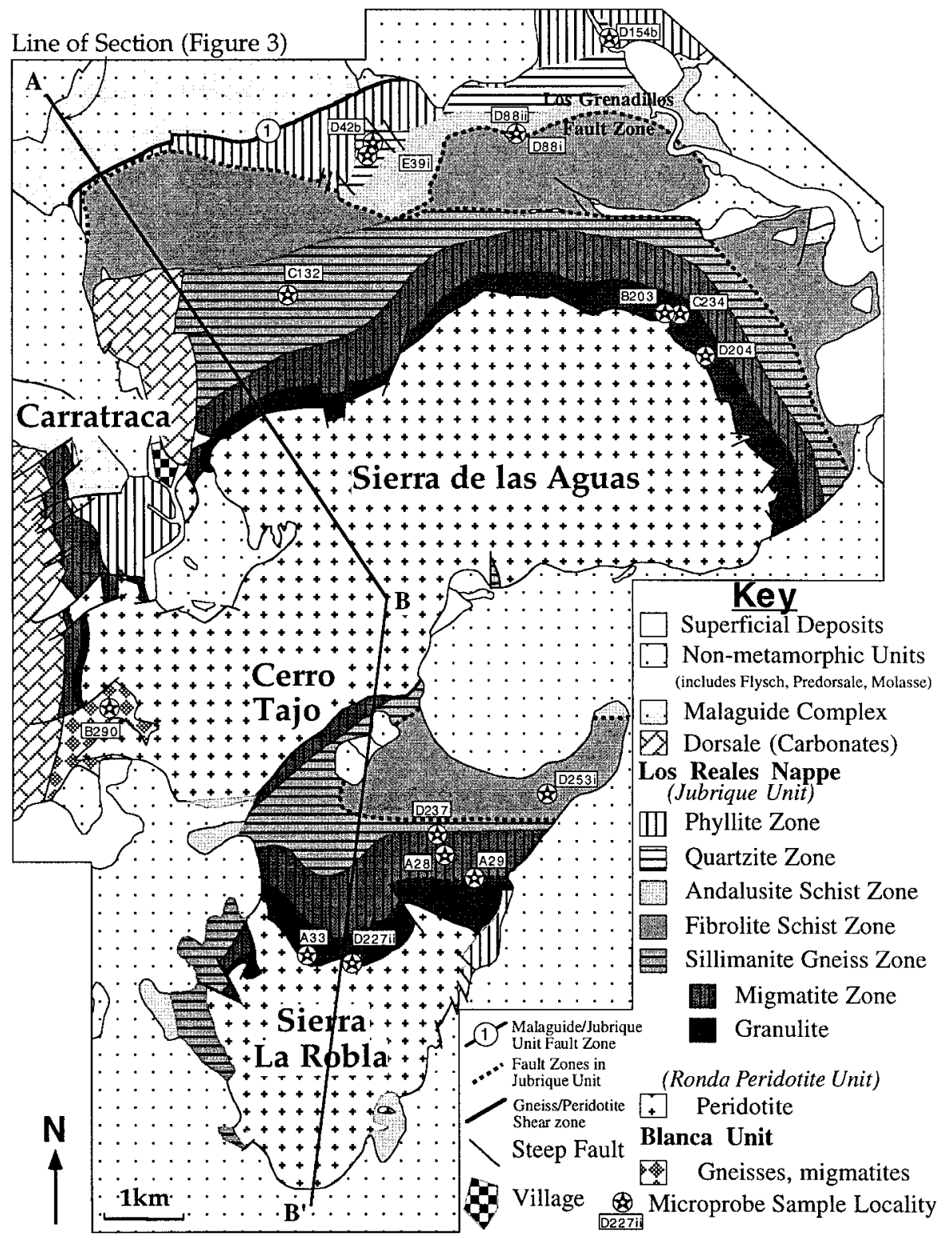

Fig. 2. Map of the Carratraca area showing tectonic subdivisions within the Alpujarride Complex, and the lithological zones in the Jubrique Unit metapelites. Also shown are major extensional fault zones in the Los Reales Nappe, and localities of samples used for Microprobe analysis.

Table 1. Jubrique Unit nomenclature and divisions

\begin{tabular}{lll}
\hline Probable age & Stratigraphical scheme & Metamorphic criteria \\
\hline $\begin{array}{l}\text { Permo-Trias } \\
\text { (non-graphitic, calcareous) }\end{array}$ & $\begin{array}{l}\text { Phyllite zone } \\
\text { Quartzite zone }\end{array}$ & Andalusite present in pelitic layers (fibrolite absent) \\
$\begin{array}{l}\text { Palaeozoic } \\
\text { (graphitic pelites) }\end{array}$ & $\begin{array}{l}\text { Andalusite schist zone } \\
\text { Fibrolite schist zone } \\
\text { Sillimanite gneiss zone } \\
\text { Migmatite zone }\end{array}$ & $\begin{array}{l}\text { Fibrolite-bearing } \\
\text { Granulite zone }\end{array}$ \\
& $\begin{array}{l}\text { Migmatitic textures } \\
\text { Granulitic domains }\end{array}$ \\
\hline
\end{tabular}

Division of the Jubrique Unit into zones. The uppermost two zones are distinguished on lithological grounds; the Andalusite schist zone is of similar grade but contains abundant graphite. Andalusite persists through the Fibrolite schist zone, but is absent in the gneisses. The Migmatite zone is distinguished by disruption (by leucosomes) of the strong banding present in the Sillimanite gneiss zone. The Granulite zone is characterised by a number of features, notably biotite breakdown textures, garnet megacrysts and NW-trending lineations. 


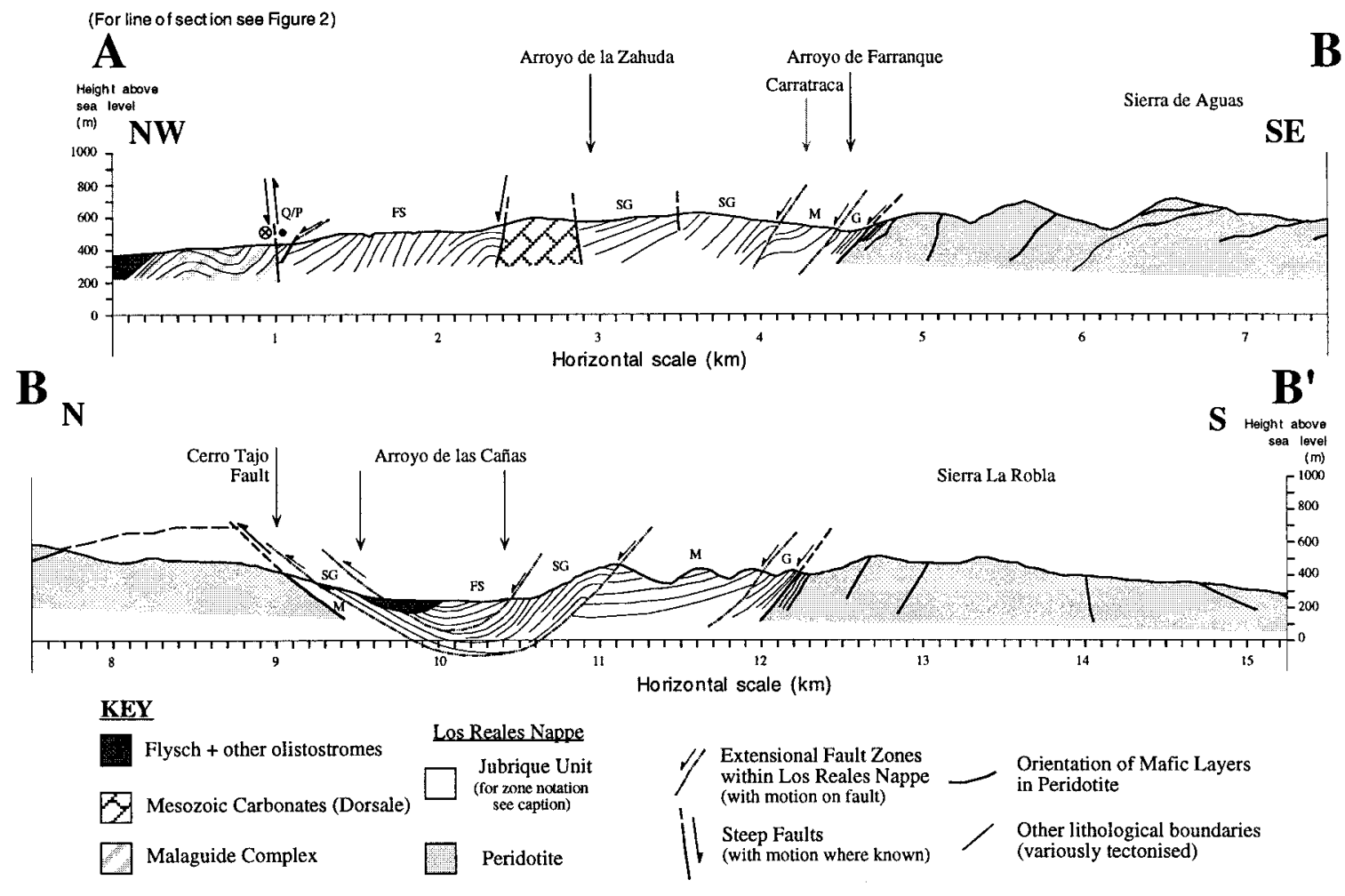

(Thin black lines represent orientation of the main foliation within metamorphic units, and bedding within the Malaguide)

Fig. 3. Cross-section through the Carratraca massif on the line shown in Fig. 2. Motion on major faults is indicated where known; see text for discussion of the complex motion history of the Malaguide/Alpujarride fault. Representation of foliations omits meso-scale folding for clarity. The relationship of the flysch units to the underlying rocks is unclear; the contact may represent a regional backthrust, or a low-angle extensional fault as suggested by Soto \& Gervilla (1991).

\section{Main foliation: nature and kinematics}

The main foliation in the Jubrique Unit (S3) is gently dipping and broadly concordant from the base of the section to the base of the non-graphitic Permo-Triassic rocks (Fig. 3). At higher levels, the transposition becomes weaker, and the dominant fabric in outcrop is the earlier foliation S2, still strongly folded but not completely transposed. In the gneisses, extensive grain growth, mineral reaction and partial melting during S3 formation erased all but a few traces of earlier fabrics. S3 steepens from 20 to $40^{\circ}$ in the schists to 60 or $70^{\circ}$ (all $\mathrm{N}$ or $\mathrm{NE}$ ) near the peridotite, possibly due to late compression: similar geometries occur adjacent to other contacts, notably with the Malaguide, and Mesozoic carbonate faultblocks (Fig. 3). Throughout the section, S3 is concordant both with internal and marginal lithological contacts and metamorphic isograds, while major fault zones are at low angles to the foliation. Unfolding the regional culmination restores the main foliation to the subhorizontal across the area, and it seems likely that this was its original orientation as there is no evidence for large-scale tectonic disruption or rotation.

$\mathrm{S} 3$ is axial-planar to mesoscale folds with flat-lying axes whose hingelines plunge NE or ENE. The obliquity of S2 relative to $\mathrm{S} 3$ changes systematically according to the changing cleavage vergence across F3 fold hinges. Peak-temperature sillimanite and rich red biotite define $\mathrm{S} 3$ in all but the highest parts of the section, where white mica and chlorite dominate. Syn-S3 minerals (Sil, Bt) wrap prograde porphyroblasts (Grt, $\mathrm{Ky}, \mathrm{St}, \mathrm{Pl}$ ), and also grow along ductile, synmetamorphic shear bands at angles of $<30^{\circ}$ to $\mathrm{S} 3$, which appear to be at least partially coeval with S3. Peak-temperature mineral stretching lineations (Sil, Qtz) throughout the sequence also trend consistently NE (Fig. 4), with the exception of those in the granulitic gneisses at the base of the Jubrique Unit, which have $\mathrm{NW}$ or $\mathrm{N}$ trends (Fig. 4). Both lineation trends occur together in the transitional Migmatite zone. NE/ENE-trending lineations also occur in a variety of settings which may be concordant or discordant (i.e. post-S3 formation). These include synmetamorphic, sillimanite-bearing veins (Fig. 4), migmatite leucosomes, retrogressed granitic and amphibolitic shear zones in the gneisses, and peraluminous granitic dykes intruding both gneisses and the marginal peridotite. NWtrending lineations, by contrast, are confined to $\mathrm{S} 3$ planes. The ENE-trending lineations are interpreted as an incomplete, or localised, overprint which becomes progressively weaker with increasing structural depth. Possible explanations for this are discussed in the following section.

Sense of shear criteria abound for the latest synmetamorphic deformation in the gneisses (porphyroblast systems, shear zones; Fig. 4); isolated porphyroblast systems give predominately, but not exclusively, SE-directed shear on NW-trending lineations and NE-directed shear on NE-trending features (Fig. 4). The schists contain many potential indicators, but of these only the shear bands and retrograde tails on porphyroblasts are reliable (Fig. 4). A shift from coaxial to non-coaxial behaviour during exhumation can be traced from conjugate synmetamorphic shear bands and regular changes in fold vergence on a $10 \mathrm{~m}$ scale, through to consistent, NE- or ENE-directed shear structures such as retrograde shear bands, brittle or semi-brittle shear fractures, and retrograde 


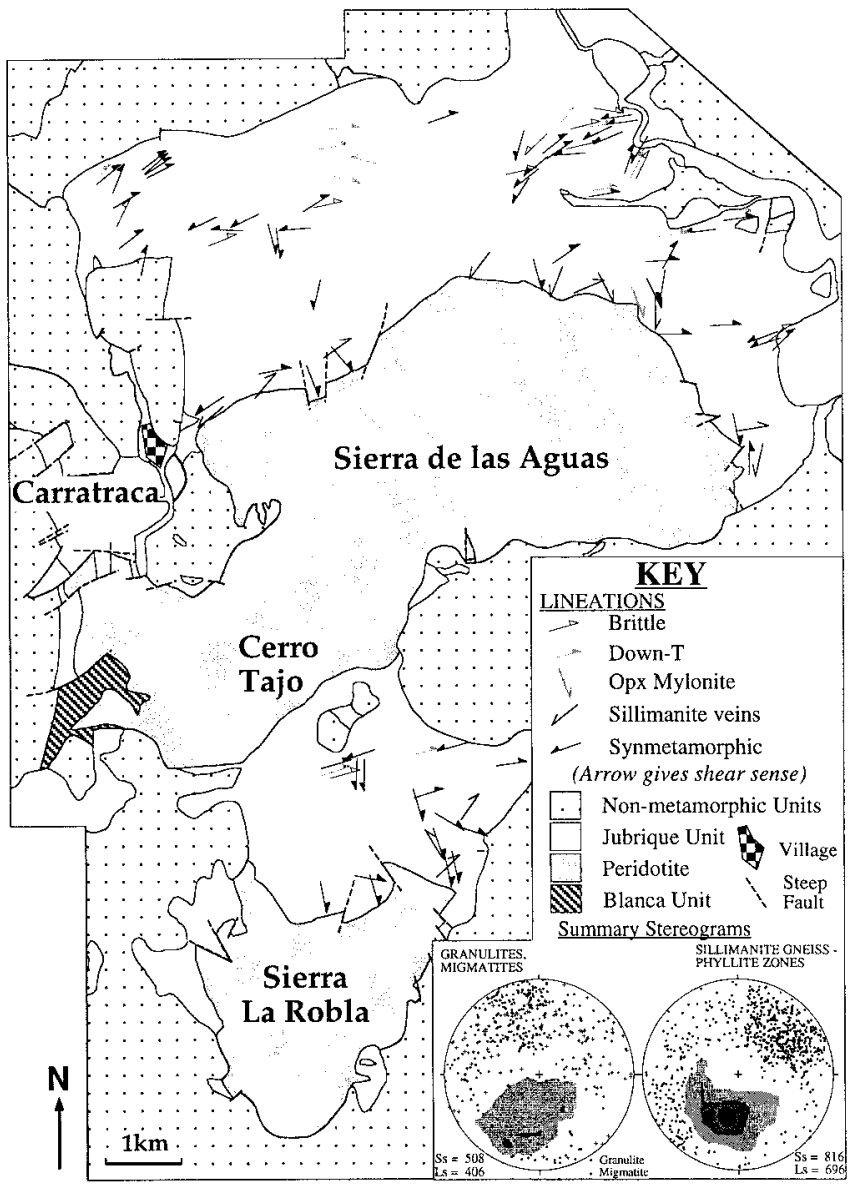

Fig. 4. Shear sense on stretching lineations (and some fibre lineations) in the Jubrique Unit. Details of kinematic indicators as follows: brittle features such as shear fractures, microfaults; down- $T$ features including retrograde shear bands and tails on garnet (all post-D3); opx mylonite representing porphyroclast systems and $\mathrm{S}-\mathrm{C}$ fabrics within the opx mylonite in sample B203; sillimanite veins with foliation deflection and fibre steps; and finally synmetamorphic criteria including porphyroblasts systems ( $\mathrm{Grt}, \mathrm{Pl}, \mathrm{Kfs}, \mathrm{St}$ ), Qtz/Qtz-Fspr bleb and boudin asymmetry, and domains of non-coaxial, peak- $T$ shear bands (with Fib, Bt). The data demonstrate the structural evolution of the Jubrique Unit from coaxial, synmetamorphic processes to increasingly non-coaxial retrograde and brittle deformation. Note predominant NW-SE trends (top-to-the-SE shear) in the granulites closest to the peridotite, in contrast to the NE and ENE trends shown by the rest of the section. Equal area stereograms show $1 \%$ contours of poles to foliation planes overlain by lineation data points for the two contrasting portions of the Jubrique Unit.

porphyroblast tails (Fig. 4). Local zones of non-coaxial, synmetamorphic shear bands may represent partitioning of overall coaxial strain into narrow, non-coaxial, (conjugate?) shear zones between macrolithons experiencing lower bulk strain.

Marginal peridotite mylonites have NE- to SE-trending enstatite lineations with rare E-directed shear sense indicators. At one locality (B203; Fig. 2), concordant, high-temperature gneiss and peridotite mylonites sharing a SE-directed shear sense are preserved, without an intervening fault gouge zone as in most other localities (Argles 1996). This suggests that these NW-SE structural trends are related to juxtaposition of the two rock-types at depth, before overprinting by the regional $\mathrm{NE} / \mathrm{ENE}$ trends formed during later coaxial and non-coaxial exhumation processes. Similar ESE-directed shear sense is observed in corresponding granulites from the Sierra Alpujata (Tubía 1994), but was reported as absent in the Sierra Bermeja by Balanyá et al. (1993).

\section{Brittle features and exhumation}

Most lithological units in the area are bounded by tectonic contacts (Fig. 2). Many of these are steep, brittle surfaces with strike-parallel or thrust motions probably related to late compression or transpression, focused on rheological contrasts (e.g. Mesozoic carbonates/Betic Zone schists). Many faults within the Jubrique Unit occur at low angles to the foliation, however, and show little evidence for thrust motions, though some strike-parallel indicators exist. Both the upper and lower boundaries of the Jubrique Unit are subparallel to adjacent structural fabrics. The lower contact juxtaposes mutually concordant peridotite mylonites with high-strain granulites across a ductile shear zone indicating crustal conditions for its formation (Obata 1980; Balanyá et al. 1993; Tubía 1994); mylonitization also occurred at lower temperatures $\left(<500^{\circ} \mathrm{C}\right.$ for antigorite and chrysotile; Wenner \& Taylor 1971) as shown by synkinematic antigorite growth (Tubía 1994). Much of this lower contact possesses a strong brittle overprint, with gouges on both sides. Fabrics from these gouges give N- or NEdirected normal motion on the contact, except for the southdipping Cerro Tajo fault (Fig. 3), where the N-directed (apparent thrust) sense reflects back-tilting of an original normal fault on the large $\mathrm{E}-\mathrm{W}$ antiform. The granulites are absent, probably excised, from the base of the section, attesting further to the originally extensional nature of the fault, where high strain rates $\left(>10 \mathrm{~cm} \mathrm{~s}^{-1}\right.$ : Sibson 1975) have generated a 2-5 m wide cataclastic breccia with injection veins of pseudotachylite in the gneiss (sensu Philpotts 1964) due to frictional melting. A similar back-tilted fault is described by Tubía (1994) from the Ojén massif.

The upper contact of the Jubrique Unit, with the Malaguide, is more complex. It preserves an initial thrust relationship (Palaeozoic over Permo-Trias), but a 'jump' in metamorphic grade, with distinctly lower grade rocks overlying higher grade ones, suggests missing section (see also Lonergan 1993; Lonergan \& Platt 1995, for the eastern Betics). Kinematic indicators (gouge fabrics etc.) for this generally steep $\left(>60^{\circ}\right)$ fault give late strike-parallel and backthrust (S-directed) motions, obscuring any earlier movements. Phyllite slivers at intervals along the contact appear to be fragments of the excised intermediate units. The fault therefore appears to preserve a complete, polyphase history of initial thrusting, followed by post-metamorphic extensional faulting and excision, and finally oblique backthrusting on the steepened contact late in the orogenic event.

Within the Jubrique Unit, several low-angle, laterally extensive, anastomosing brittle fault zones occur (Fig. 2). Rarely well exposed, they can be up to $50 \mathrm{~m}$ wide, commonly appearing diffuse but representing considerable excision of section (e.g. at least $2 \mathrm{~km}$ across the Los Grenadillos fault zone, Fig. 2). Rare kinematic indicators give $\mathrm{N}$ - and NE- directed normal motions, with subsidiary strike-parallel lineations. The most significant zone divides the Jubrique Unit into schists (upper) and gneisses (lower), and merges with the Los Grenadillos fault zone to the NE of Carratraca (Fig. 2). This may reflect a large-scale conjugate geometry to the faults. Extensional motion on all the faults mentioned above was undoubtedly a dominant factor in the exhumation and attenuation of the rocks. 
Table 2. Samples used for microprobe analysis

\begin{tabular}{|c|c|c|c|}
\hline Sample & Grid Ref. & $\begin{array}{c}\text { Height in } \\
\text { section }(\mathrm{m})^{*}\end{array}$ & $\begin{array}{c}\text { Mineral assemblage } \\
\text { (decompression phases in bold type); } \\
\text { (abbreviations from Kretz 1983) }\end{array}$ \\
\hline D154b & [434857] & 2200 & Qtz-Pl-Wm-Chl-Ep-Ky-Gr \\
\hline $\mathrm{D} 42 \mathrm{~b}$ & [405844] & 1700 & Qtz-Pl-St-Cld-Wm-Bt-Chl-Ep-Ky-Gr; Ep-Amph in blebs \\
\hline E39i & [463834] & 1650 & Qtz-Ky-Wm-Pl-Chl (vein) + Sph-Amph-Dol-Gr (schist) \\
\hline D88ii & [421846] & 1450 & Qtz-Pl-Grt-St-Ky-Bt-And-Wm-Ilm-Gr \\
\hline D88i & [421846] & 1400 & Qtz-Pl-Grt-St-Ky-Bt-Fib-Wm-Ilm-Chl-Rt-Gr \\
\hline D253i & [427760] & 1200 & Qtz-Pl-Grt-St-Wm-Bt-Fib-And-Ilm-Rt-Gr \\
\hline $\mathrm{C} 132$ & [394824] & 1050 & Qtz-Pl-Grt-Bt-Ky-Kfs-Crd-Fib-And-Ilm-Gr \\
\hline D237 & [413755] & 500 & Qtz-Kfs-Pl-Grt-Crd-Fib-Tur-Bt +Wm, Chl (retrograde) \\
\hline E11 & [425824] & 475 & Qtz-Pl-Kfs-Grt-Crd-Sil-Bt-Ilm -Gr + Wm (retrograde) \\
\hline A28 & [413752] & 275 & Qtz-Pl-Kfs-Grt-Crd-Bt-Sil-Ilm-Rt-Gr \\
\hline A29 & [421748] & 150 & Qtz-Pl-Kfs-Grt-Crd-Bt-Sil-Hc-Ilm-Gr \\
\hline C234ii & [444821] & 50 & Qtz-Grt-Cpx-Parg-Pl-Opx-Sph-Ilm \\
\hline A33 & [397736] & 10 & Qtz-Pl-Kfs-Grt-Ky-Bt-Crd-Sil-Hc-Ilm-Rt-Gr \\
\hline B203 & [443821] & 0.5 & Qtz-Pl-Kfs-Grt-Ky-Bt-Crd-Sil-Opx-Hc-Ilm-Rt-Gr \\
\hline D204i & [447815] & 0.4 & Grt-Pl-Sil-Ky-Crd-Bt-Hc-Ilm-And +Wm/Chl/Cal (retro.) \\
\hline D227i & [405740] & -1 & Cpx-Grt-PI-Opx-Hbl-Ilm \\
\hline B290 & [373771] & $-50 \dagger$ & Qtz-Pl-Kfs-Crd-Bt-Fib-And-Ilm + Wm (retrograde) \\
\hline
\end{tabular}

* Measured from upper peridotite contact.

$\dagger$ Measured from lower peridotite contact.

\section{Metamorphic history and thermobarometry of the Jubrique Unit}

\section{Overview}

We have divided the metamorphism related to the Alpine orogeny into two stages, prograde and decompression, for clarity, though these were probably part of a continuous cycle. The prograde stage includes assemblages formed on the uptemperature $P-T$ path, including the earliest stages in the S3 formation; full mineral assemblages for samples throughout the Jubrique Unit are summarized in Table 2. Information on the prograde stage is abundant in the schists (as inclusion suites in garnet, staurolite, kyanite and plagioclase porphyroblasts), but early assemblages were extensively reworked in the gneisses by later metamorphism. This dichotomy is illustrated by a suite of aluminium-silicate-bearing veins predating S3 formation, in which kyanite is preserved only in the uppermost schists; at intermediate levels kyanite is replaced by andalusite, and in the gneisses by sillimanite. Mineral growth during the decompression falls into two groups: syn- and post-S3 formation, whose relative importance varies between individual rock-types, localities, or even microscopic domains. Syn-D3 growth in the $\mathrm{S} 3$ foliation is common below the Permo-Triassic rocks, but there is a general trend towards more widespread post-tectonic mineral growth in the higher parts of the section, and in the gneisses late mineral growth may be locally more extensive due to the higher temperatures prevalent at the lowest structural levels. Decompression-related minerals are highlighted for specific samples in Table 2. Both syn- and post-D3 aluminium-silicate-bearing veins occur in the section, similar to suites described by Cesare (1994), which mirror the metamorphic history recorded in the metapelites. Many syn-D3 veins are lineated parallel to the D3 stretching lineation, while post-D3 veins occupy extensional sites such as foliation boudin necks and shear fractures. Retrograde metamorphism is restricted throughout the Jubrique Unit, confined mainly to semi-brittle shear bands, shear zones and the vicinity of fault zones. These retrograde features give consistent NE- directed shear, as do the later entirely brittle features, illustrating the shift towards non-coaxial behaviour with exhumation.

Throughout the Jubrique Unit the petrography outlines a 'typical' prograde history related to crustal thickening and burial of rocks, followed by rapid, isothermal decompression. While diachroneity of metamorphism through the section may introduce error into the depth estimates, these errors are likely to be small compared to those on the $P-T$ data, especially during the more recent history when the section was already thinned. To a first-order approximation, a low-pressure metamorphic field gradient (Fig. 5) can be taken to represent the geothermal gradient in the section during decompression; the rapidity of the exhumation and structural constraints suggest this to be justified within the context of these necessarily crude calculations. The following section describes thermobarometric studies on specific samples to illustrate, and quantify, the $P-T$ evolution of the Jubrique Unit in more detail.

\section{Sample petrography and thermobarometry}

Seventeen samples were analysed using the Microscan Electron Microprobe at Oxford at an accelerating potential of $20 \mathrm{kV}$, beam current $4 \times 10^{-8} \mathrm{~A}$, and beam size of $0.5-1.0 \mu \mathrm{m}$. 15 samples were from the Jubrique Unit, one from the peridotite margin, and one from the Blanca Unit which underlies the peridotite. Their characteristics are summarized in Table 2.

Thermobarometric results are presented in Fig. 5. A variety of methods was employed (Fig. 5 and below), reflecting the requirements of each assemblage; throughout the section these relied heavily on $\mathrm{Fe}-\mathrm{Mg}$ exchange for thermometry (e.g. Grt-Bt; Bhattacharya et al. 1992), and Ca exchange between garnet and plagioclase for barometry. For garnet-absent samples, the silica in phengite barometer (Massonne \& Schreyer 1987) was used. As far as possible, activity models used in the calibrations were kept consistent across the methods used; the activity calculation program Ax (Holland 1993) was used for all phases except white mica in D154b, where the assumption of $\mathrm{Fe}_{\text {tot }}=\mathrm{Fe}^{++}$ was used for the Fe-celadonite end-member. For partially molten metapelites, the program Thermocalc (Powell \& Holland 1988) was used to construct phase diagrams for assemblages lying on the solidus, since equilibrium between solid phases and water-undersaturated melt constrains $a\left(\mathrm{H}_{2} \mathrm{O}\right)$. Approximate values for $a\left(\mathrm{H}_{2} \mathrm{O}\right)$ at the pressure and 


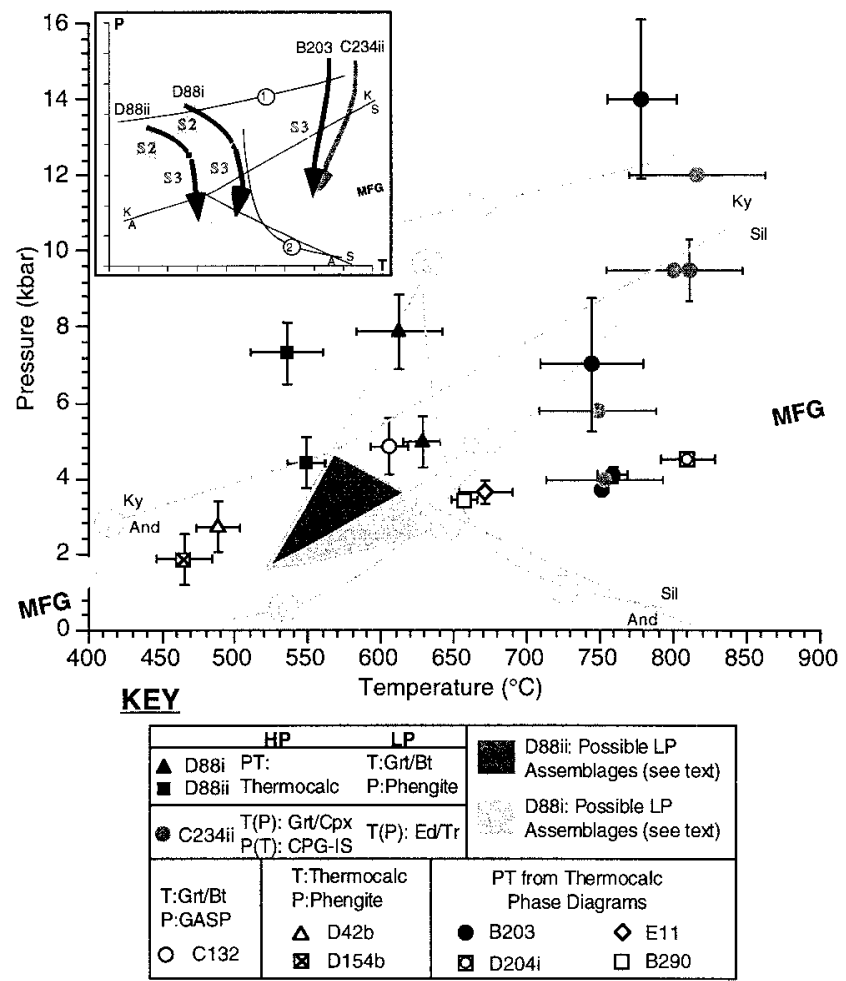

MFG : Shaded arrows define LP 'metamorphic field gradient' discussed in text

Fig. 5. Summary of $P-T$ data for the Jubrique Unit in the Carratraca area, with inset illustrating deduced $P-T$ paths for individual samples, and their relation to tectonic episodes. Both pelitic and mafic assemblages show near-isothermal decompression at peak $T$, and the data form a low-pressure array (grey arrows) taken as a metamorphic field gradient which is employed in thermal modelling (see text for discussion). Shaded portions of $P-T$ paths in the inset diagram indicate timing of fabric-forming episodes (S2, S3 as shown). Equilibria used to constrain $P-T$ (grey lines): (1) $\mathrm{Alm}+\mathrm{Rt}=\mathrm{Ilm}+\mathrm{Ky}+\mathrm{Qtz}$ (Bohlen et al. 1983); (2) haplogranite solidus (Keppler 1989); (3) $\mathrm{Chl}+\mathrm{Ms}+\mathrm{Grt}=\mathrm{Bt}+\mathrm{St}+\mathrm{Qtz}$; (4) Approximate lower pressure limit of Staurolite; (5) $\mathrm{Ms}+\mathrm{Grt}=\mathrm{Bt}+\mathrm{Crd}+\mathrm{And} ;(6) \mathrm{Ms}+\mathrm{Qtz}=\mathrm{Kfs}+\mathrm{Als}+\mathrm{H}_{2} \mathrm{O}$ (all Xu et al. 1994); (7) aluminium silicate stabilities (Holland \& Powell 1990). The above equilibria are used to constrain $P-T$ paths for D88i \& ii near the AlSilicate triple point (see discussion in text).

Thermobarometry: Thermocalc (Powell \& Holland 1988); Grt/Bt (Bhattacharya et al. 1992); Phengite (Massonne \& Schreyer 1987); Grt/Cpx (Pattison \& Newton 1989); CPG-IS (Mukhopadhyay et al. 1992); Ed/Tr (Holland \& Blundy 1994); GASP (Holland \& Powell 1990). All errors include a $1 \%$ analytical error; those for high-grade rocks relate to phase diagram uncertainties, as discussed in the text.

temperature of interest were determined by interpolation of $X\left(\mathrm{H}_{2} \mathrm{O}\right)$ from the experimentally determined solidus for haplogranite in $\mathrm{H}_{2} \mathrm{O}$ $\mathrm{CO}_{2}$ vapour (Keppler 1989), combined with Holland \& Powell's (1990) model for non-ideal mixing in $\mathrm{H}_{2} \mathrm{O}-\mathrm{CO}_{2}$ vapour. The resulting phase diagrams show univariant reaction curves in $P-T$ space for specified systems (in this case KFMASH) with accompanying divariant assemblage fields contoured for mineral composition (e.g. $X(\mathrm{Mg})$ ). A similar diagram was presented by Waters (1991), for aluminous migmatitic metapelites. Uncertainties given for results using this method (Fig. 5) incorporate initial Microprobe analysis errors of $1 \%$, but chiefly result from the discrepancies between composition isopleths for the different phases within divariant assemblages on the phase diagrams. These discrepancies reflect different degrees of disequilibrium (e.g. diffusional re-setting) in the compositions of the phases. Where divariant assemblage isopleths are almost independent of either pressure or tempera- ture, large uncertainties result unless constrained by other equilibria (e.g. Al silicate reactions).

Two gneiss samples, B203 (a metapelitic granulite), and C234ii (a mafic granulite), were analysed to provide well-constrained $P-T$ paths (Fig. 5). Unoriented high-pressure assemblages $(\mathrm{Qtz}+\mathrm{Pl}+\mathrm{Ky}+\mathrm{Rt})$ occur in the cores of the largest garnet porphyroblasts (up to $4 \mathrm{~cm}$ ) in B203, while some kyanite is preserved in the external foliation, or represented by sillimanite pseudomorphs. Garnet cores contain up to $13 \mathrm{Wt} \% \mathrm{MgO}$ (Fig. 6), though almandine dominates (20-30 wt \% FeO). Unsystematic variation in $\mathrm{MnO}$ and $\mathrm{CaO}$ in the cores of the largest porphyroblasts may represent relicts of growth zoning. Ilmenite and sillimanite replace the rutile/kyanite core association in the outer portions of the garnets, reflecting incipient decompression and/or temperature increase during the formation of $\mathrm{S} 3$, as observed for the rest of the section. Garnet, antiperthitic plagioclase and perthitic Kfeldspar porphyroblasts are wrapped by the main foliation defined by sillimanite, ilmenite and biotite; leucocratic domains indicate partial melting related to breakdown of white mica. More Fe-rich and Mg-poor garnet compositions than the cores are prevalent, with a wide plateau in some cases across the whole crystal, suggesting high-temperature diffusional homogenization. Retrograde diffusional rims (Fig. 6), particularly pronounced adjacent to cordierite coronas, suggest extensive low-pressure $\mathrm{Fe} / \mathrm{Mg}$ exchange. The cordierite coronas, commonly ringed by a hercynite spinel-anorthite symplectite adjacent to sillimanite or kyanite, are part of the lowpressure overprint, along with $\mathrm{Crd}-\mathrm{Ilm}-\mathrm{Hc}$ domains produced by static biotite breakdown. A coarse, Crd-Grt-An-Spl contact hornfels (D204i) represents a rare case of these reactions going to completion; most were inhibited by low fluid contents in the rocks. Adjacent to one ductile peridotite/gneiss contact, sample B203 also contains thin mylonitic seams paralleling the contact with orthopyroxene neoblasts in a groundmass of deformed low-pressure corona phases, representing the final discrete, ductile deformation at 12-14 depth.

Sample C234ii was taken from mafic boudins wrapped strongly by metapelitic gneiss similar to B203. High pressure phases (Grt-Cpx-Sph) are rimmed by pargasitic hornblende and later, symplectitic Pl-Opx coronas; sphene is replaced by symplectites containing ilmenite.

The Thermocalc-generated path for B203 (Fig. 5) corresponds well to the path for C234iii, constructed using conventional barometers (clinopyroxene-plagioclase-garnet-ilmenitetitanite (CPG-IS) of Mukhopadhyay et al. (1992); garnetorthopyroxene-plagioclase-quartz (GOPQ) of Holland \& Powell (1990)), and thermometers (Grt-Cpx Fe/Mg exchange of Pattison \& Newton (1989); Ed-Tr of Holland \& Blundy (1994)). Both samples show strong, near-isothermal decompression from around $12-14 \mathrm{kbar}$ to around $4 \mathrm{kbar}$ at $750-800^{\circ} \mathrm{C}$. All results are shown on Fig. 5, with the exception of GOPQ for $\mathrm{C} 234 \mathrm{ii}\left(5.8 \pm 1.5 \mathrm{kbar}\right.$ for $\left.750^{\circ} \mathrm{C}\right)$, which is omitted to avoid congestion but falls in the same low-pressure region.

Higher in the section, the two adjacent samples D88i (fibrolite schist zone) and D88ii (andalusite schist zone) provide information not only on $P-T$ paths at this level, but also on excision across the fault zone which they straddle. Prograde minerals in D88ii include embayed kyanite and garnet, with later staurolite, all wrapped by $\mathrm{S} 3(\mathrm{Bt}, \mathrm{Wm})$. Biotite also defines late shear bands, while andalusite overgrew S3 statically (surrounding pelites show spectacular post-tectonic andalusite development). Garnets in D88ii are resorbed, with St-And-Bt-Ms stable; garnets preserve prograde growth 
a) D25 3i: Fibrolite-bearing schist

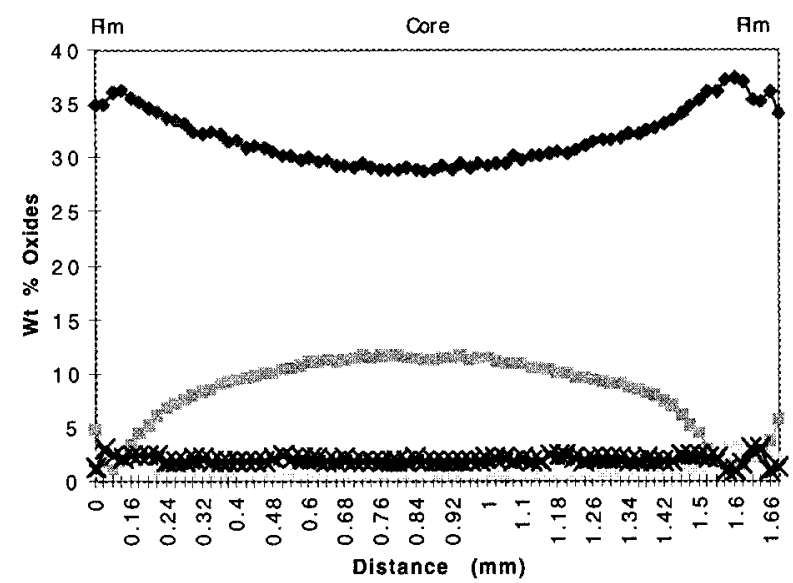

c) E11: Migmatite

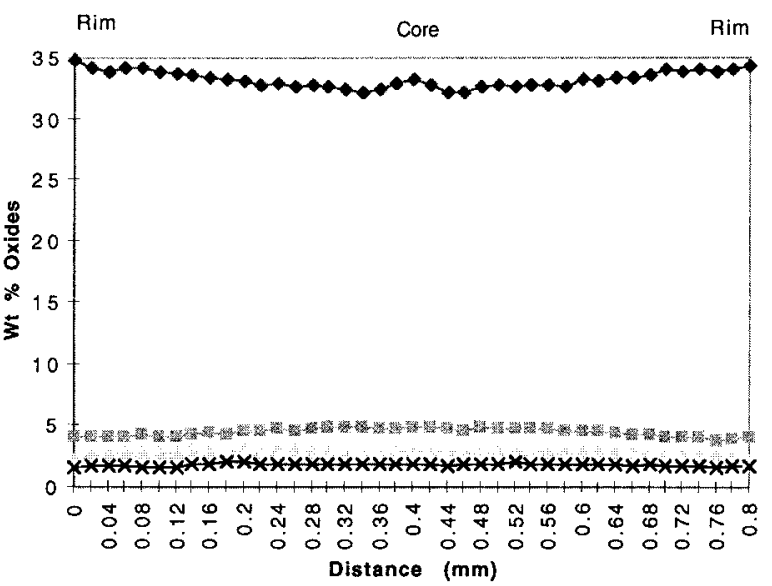

b) B203: Peli tic granulite

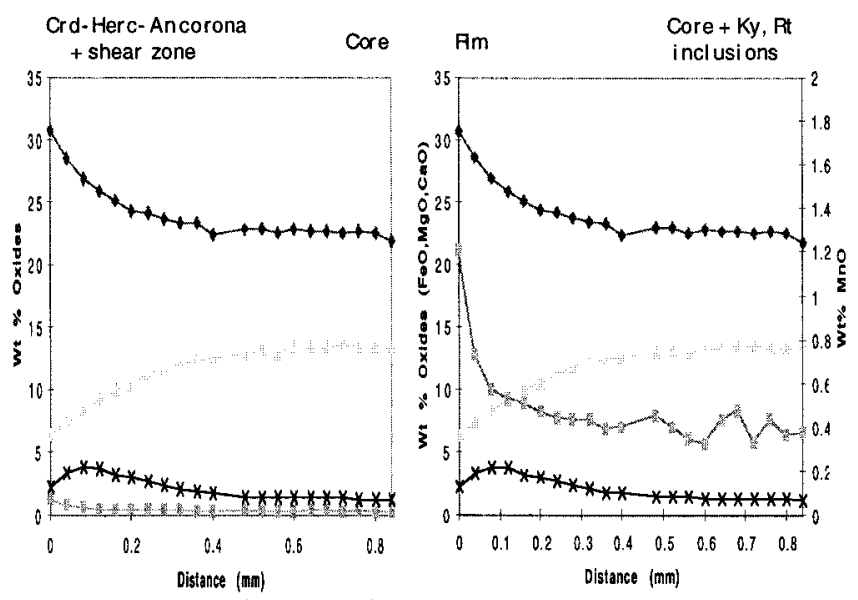

(Key as before; diagram on right

plots $\mathrm{MnO}$ at a different scale)

\section{d) C237a: Grt-Tur-Leucogranite}

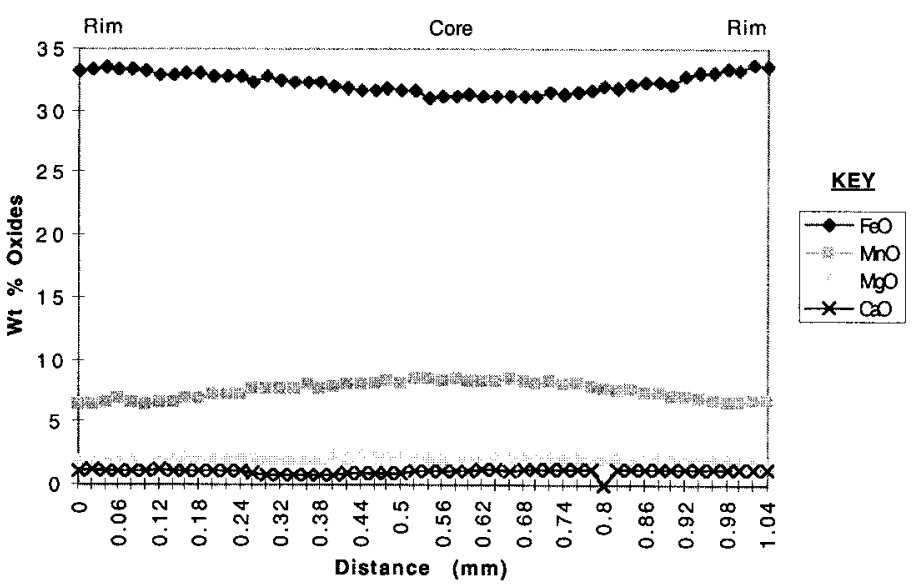

Fig. 6. Garnet zoning profiles, Jubrique Unit. In D253i, a pelitic schist from the top of the Fibrolite schist Zone, garnets show growth zoning with rims modified by retrograde diffusion; the other examples all show some degree of homogenization. B203 garnets have wide rims with diffusion zoning, while garnets from the Migmatite Zone (E11, C237a) show almost flat profiles and elevated MnO contents.

zoning (core to rim decrease in MnO; see also Sample D253i in Fig. 6, with secondary overgrowth). These relations define a stability field of $515-620^{\circ} \mathrm{C}$ and $1.5-4.6 \mathrm{kbar}$ (Fig. 5), with the lack of fibrolite further suggesting likely temperatures during decompression of $<570^{\circ} \mathrm{C}$. D88i, in the footwall of the fault zone, has coarser prograde minerals (Grt-St-Ky-Pl-Rt) wrapped by $\mathrm{S} 3$ defined by coarse muscovite microfolds with axial-planar biotite laths intergrown with fibrolitic sillimanite. Other schists at this level contain post-tectonic andalusite with fibrolite on shear bands (outside the sillimanite stability field; see Kerrick 1990, and references therein). D88i shows staurolite breakdown in the sillimanite field with no significant breakdown of white mica; samples above and below D88i contain staurolite armoured in andalusite, but cordierite is absent from D88i. These relations suggest conditions of 515 $640^{\circ} \mathrm{C}$ and $1.5-3.6 \mathrm{kbar}$ from the calculated grid of $\mathrm{Xu}$ et al. (1994), while homogenized garnets in D88i indicate that temperatures of $615-655^{\circ} \mathrm{C}$ persisted for a significant time after their formation (Yardley 1977) (Fig. 5). Rutile is present in D88i but not D88ii; this gives some indication of the prograde conditions. Excision across the fault zone (Table 3) was calculated using the Phengite barometer (Massonne \&
Schreyer 1987) and Grt-Bt thermometer (Bhattacharya et al. 1992) with a geothermal gradient calculated for the whole section during the low-pressure event. Neither sample contains $\mathrm{K}$-feldspar, but the minimum pressure values obtained as a result can still be compared as an estimate of original separation. The two figures for section missing between D88i and D88ii are almost identical (approximately $2 \mathrm{~km}$ ).

D154b, a sample of phyllite near the top of the section, was used for $P-T$ estimates in the upper levels. Garnet is rare in the phyllites, but Thermocalc gives relatively high pressures $(7.9 \pm 0.6 \mathrm{kbar})$ for the temperature $\left(463 \pm 10^{\circ} \mathrm{C}\right)$, based on the co-existence of kyanite with magnesian chlorite, epidote and albite. Goffé et al. (1989) report magnesian carpholite from the uppermost levels of the Alpujarride; its absence here may reflect the extensive metamorphic re-working which also eliminated almost all early chloritoid and chlorite. Some post-tectonic andalusite occurs at similar levels in the section. The low-pressure portion of the $P-T$ path is only constrained by the phengite barometer (Massonne \& Schreyer 1987) to $1.9 \pm 0.7 \mathrm{kbar}$, and to roughly isothermal decompression by the lower $T$ limits of staurolite and chloritoid $\left(420-470^{\circ} \mathrm{C}\right.$; Spear \& Cheney 1989). 
Table 3. Attenuation calculations

\begin{tabular}{|c|c|c|c|c|c|c|}
\hline $\begin{array}{l}\text { Portion of } \\
\text { exhumation } \\
\text { calculated }\end{array}$ & $\begin{array}{c}\text { Samples } \\
\text { used }\end{array}$ & $\begin{array}{c}\text { Current } \\
\text { structural } \\
\text { separation } \\
(\mathrm{km})\end{array}$ & $\begin{array}{c}P-T \\
\text { difference } \\
T\left({ }^{\circ} \mathrm{C}\right) \\
P(\mathrm{kbar})\end{array}$ & $\begin{array}{c}\text { Original } \\
\text { separation } \\
\text { (calculated; } \\
\text { km) }\end{array}$ & $\begin{array}{l}\text { Attenuation } \\
\text { factor }\end{array}$ & $\begin{array}{c}\text { Conversion } \\
\text { factors }(P-T) \\
T\left({ }^{\circ} \mathrm{C} \mathrm{km}{ }^{-1}\right) \\
P\left(\mathrm{~km} \mathrm{kbar}^{-1}\right)\end{array}$ \\
\hline Total & $\begin{array}{l}\text { D154b } \\
\text { B203 }\end{array}$ & 2.2 & $\begin{array}{l}T: 314 \pm 31 \\
P: 6.1 \pm 2.2\end{array}$ & $\begin{array}{c}\text { (from } P \text { data) } \\
21.4 \pm 7.7\end{array}$ & $\begin{array}{c}\text { (from } P \text { data) } \\
9.70 \pm 3.5\end{array}$ & $\begin{array}{c}T: 14.7 \pm 5.5 \\
P: 3.5^{*}\end{array}$ \\
\hline Brittle & $\begin{array}{l}\text { D154b } \\
\text { B203 }\end{array}$ & 2.2 & $\begin{array}{l}T: 294 \pm 21 \\
P: 2.2 \pm 0.7\end{array}$ & $\begin{array}{c}\text { (from } P \text { data) } \\
7.70 \pm 2.5\end{array}$ & $\begin{array}{c}\text { (from } P \text { data) } \\
3.50 \pm 1.1\end{array}$ & $\begin{array}{c}T: 38.2 \pm 12 \\
P: 3.5\end{array}$ \\
\hline Brittle & $\begin{array}{l}\text { D154b } \\
\text { B204 }\end{array}$ & 2.2 & $\begin{array}{l}T: 345 \pm 26 \\
P: 2.6 \pm 0.7\end{array}$ & $\begin{array}{l}\text { (from } P \text { data) } \\
9.10 \pm 2.5\end{array}$ & $\begin{array}{c}\text { (from } P \text { data) } \\
4.14 \pm 1.1 \\
\text { Section lost }\end{array}$ & $\begin{array}{c}T: 37.9 \pm 11 \\
P: 3.5\end{array}$ \\
\hline $\begin{array}{l}\text { Excision } \\
\text { (at fault zone) }\end{array}$ & $\begin{array}{l}\text { D88ii } \\
\text { D88i }\end{array}$ & 0.05 & $\begin{array}{l}T: 80 \pm 18 \\
P: 0.6 \pm 1\end{array}$ & $\begin{array}{l}T: 2.1 \pm 0.5 \\
P: 2.1 \pm 3.5\end{array}$ & $\begin{array}{l}T: 2.05 \pm 0.5 \\
P: 2.05 \pm 3.5\end{array}$ & $\begin{array}{l}T: 38 \\
P: 3.5\end{array}$ \\
\hline
\end{tabular}

*Figures in italics are fixed values used in calculations

Four calculations using $P-T$ data from the Jubrique Unit to constrain vertical attenuation, and in one case excision, of the section. 'Total' attenuation uses $P-T$ data for the earliest quantifiable metamorphic event, and estimates the amount of thinning since then due to both ductile and brittle processes for a section between samples D154b and B203. The two 'brittle' calculations use $P-T$ data from the latest recorded (LP) metamorphism, estimating the amount of thinning since that event, with two different samples from the peridotite/gneiss contact for comparison. It is assumed this attenuation was accomplished by predominately brittle processes. The final calculation estimates the section excised across a single fault zone using $P-T$ data from samples in the footwall and hanging wall, with the original thermal gradient given by the two previous calculations. Errors from $P-T$ data are rigorously propagated through the calculations. See text for a discussion of the implications of the calculations.

The use of $\mathrm{D} 154 \mathrm{~b}$ for $P-T$ estimations and in the attenuation calculations (Table 3 ) is supported by the trend of the low-pressure metamorphic field gradient through the section (Fig. 5), which can be approximated to a geothermal gradient for this stage of the metamorphic history. Petrographic evidence (e.g. abundant andalusite in sample C132) supports this assumption by corroborating points in the array. The calculated pressures for D88i, ii and C132 (displaced slightly above the trend defined by the rest of the section) were obtained using the garnet-aluminium silicate-plagioclase-quartz (GASP) (Holland \& Powell 1990) and may reflect early closure of refractory mineral systems (e.g. Pl, Grt etc.) on the decompression path which did not affect the phengite system or the high-grade assemblages. Petrography on individual samples indicates isothermal decompression throughout the section; e.g. for samples giving peak temperatures of about $550^{\circ} \mathrm{C}$ (D88i \& ii, C132), the $P-T$ paths can be tightly constrained using the position of the Al silicate invariant point (after Holland \& Powell 1990), and several equilibria involving the breakdown of staurolite (D88i, C132), garnet (D88ii), and the relative stabilities of staurolite, muscovite, cordierite and K-feldspar (Xu et al. 1994). The contact hornfels D204i gives an upper limit of $810 \pm 18^{\circ} \mathrm{C}$ for the Jubrique Unit, while estimates for D227ii, a mafic layer just within the peridotite, give temperatures of $770-790^{\circ} \mathrm{C}$ for symplectitic Hbl-Pl decompression coronas at any pressure less than $10 \mathrm{kbar}$, according excellently with temperatures in the crustal rocks during decompression. The earlier history of D227ii is poorly constrained, but Grt-Cpx (Pattison $\&$ Newton 1989) determinations on core analyses suggest preexhumation temperatures of at least $1100^{\circ} \mathrm{C}$, in agreement with Van der Wal's (1993) assessment.

If the above metamorphic field gradient is taken as a guide to a thermal gradient at a time just after the cessation of pervasive ductile deformation in the section, a series of simple calculations can be performed to approximate the amount of attenuation, and excision across fault zones, that has occurred in the Jubrique Unit since then. Indications are that the section behaved as a coherent entity during the latest stages of ductile deformation, and thus any diachroneity of structural events from base to top was minimal. Since the low-pressure metamorphic event shows only slight diachroneity through the section relative to the latest ductile deformation, overall the diachroneity of metamorphism is negligible when considering the first-order estimations that follow. Needless to say the errors on these calculations are large, but since each calculation takes the difference between two sets of thermobarometric data with identical systematic uncertainties (i.e. obtained using the same thermodynamic data, activity models etc.), the errors on the attenuation factors are upper limits, and may be as little as $15-20 \%$. The results are summarized in Table 3.

All calculations use a conversion factor of $3.5 \mathrm{~km}: 1 \mathrm{kbar}$ to estimate original structural separation between two samples from geobarometric data. This assumes the two samples record coeval pressures, as discussed previously. The first three calculations compare original with present-day structural separation, resulting in a measure of the attenuation that part of the section has experienced since the pressures were recorded. Thermal gradients between the two samples at each stage are obtained by dividing the temperature difference from geothermometry by the original structural separation; values of about $38^{\circ} \mathrm{km}^{-1}$ are given by both the latest metamorphic stage estimates (calcs. 2 \& 3).

The final calculation compares $P-T$ data for two samples separated by a fault zone. The pressure difference across the fault zone represents $2.1 \mathrm{~km}$ original separation, most of which was excised during faulting. A similar value is obtained when the temperature difference across the fault is divided by the thermal gradient $\left(38^{\circ} \mathrm{km}^{-1}\right)$ for the latest metamorphism (i.e. just prior to faulting). Figure 7 is a schematic model of the Jubrique Unit exhumation incorporating these calculations.

\section{Discussion}

Since the work of Dickey (1970) and Loomis $(1972 a, b)$ on the Ronda Peridotite, these outcrops of mantle lherzolite have 


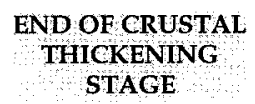

\section{LATEST \\ DUCTILE DEFORMATION}

\section{PRESENT} OUTCROP

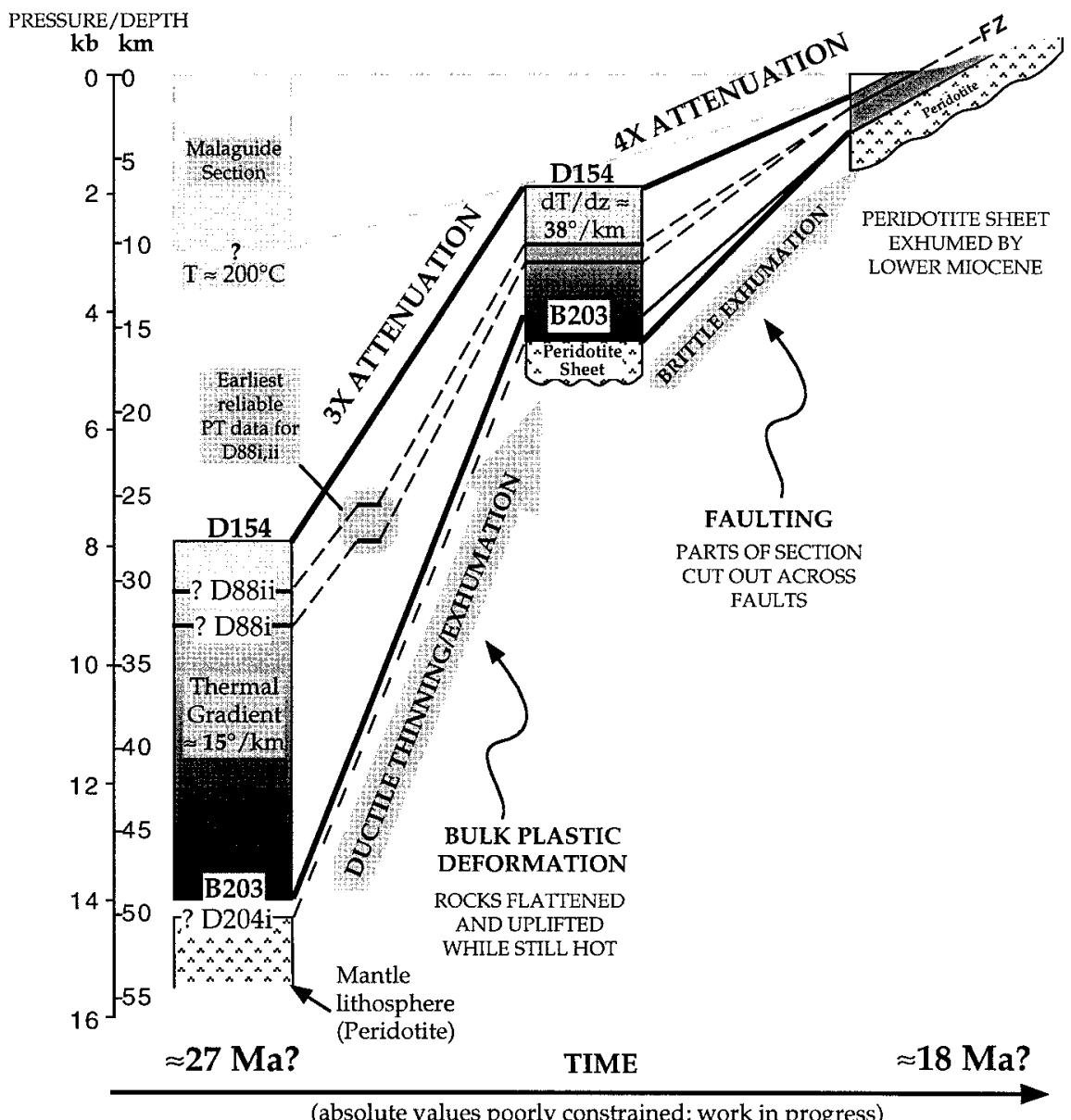

Fig. 7. Schematic model showing the exhumation path and attenuation of the Jubrique Unit from a point in the section's history just prior to S3 formation and exhumation (i.e. the earliest reliable $P-T$ data points) to the present day (top right). Two stages of exhumation are distinguished; an initial stage dominated by ductile and semi-ductile processes (essentially bulk thinning), followed by a brittle exhumation stage where section was excised across extensional faults and deep rocks were passively exhumed with negligible internal deformation. The contribution of fault excision is illustrated at locality D88 for one of a number of faults in the study area. Estimated thermal gradients are shown schematically for the first two stages, to emphasize the advection of heat to shallow levels. The Malaguide complex is included as a first-order illustration of higher crustal levels (including Oligocene surface deposits) (Lonergan 1993), based on the assumption that the base of the section never exceeded $200^{\circ} \mathrm{C}$ (Lonergan \& Platt 1995). Dating is currently in progress in the area to improve the model. attracted considerable study and speculation as to their origin. Their essentially undifferentiated mantle character (Dickey 1970; Kornprobst 1974) prompted some authors to suggest they represented outcrops of a steep-sided diapiric intrusion rooted in the mantle (Loomis 1972b; Darot 1974); more recently Doblas \& Oyarzun (1989) even suggested the massifs represented surface outcrops of a mantle lithosphere 'core complex' culmination. However, work by Lundeen (1978), Torné et al. (1992) and others has demonstrated the sheet-like geometry of the peridotite; gravity profiles suggest a tectonic sheet dipping gently $\mathrm{SE}$, with a maximum thickness of $8 \mathrm{~km}$, sandwiched between Alpujarride crustal nappes.

The peridotite was tectonically emplaced in the solid state into crustal metapelites of the Jubrique Unit, as shown by the relict ductile contacts at the top of the sheet in the Carratraca area (this study) and the Sierra Alpujata (Tubía pers. comm.). Thermobarometry on the concordant structures in the peridotite and the adjacent gneisses suggest the two components of the Los Reales nappe were first juxtaposed at 40-50 km depth, along a major shear zone defined by mylonitic fabrics in both rock-types, at temperatures of $850^{\circ} \mathrm{C}$ for the peridotite (Van der Wal 1993; Tubía 1994) and $780^{\circ} \mathrm{C}$ for the crustal granulites (Fig. 5). This corresponds to the 'shear zone with neutral geometry' of Balanyá et al. (1993), suggested indirectly by van Wees et al. (1992) as a mechanism for partial exhumation of the peridotite. Higher temperatures $\left(1100^{\circ} \mathrm{C}\right)$ are recorded deeper in the peridotite sheet by a distinct annealing front caused by a heat source at depth (Van der Wal \& Bodinier 1996).

Initially, the abrupt decrease from granulite to greenschist facies away from the peridotite contact in the Jubrique Unit was considered to be a thermal aureole (Loomis 1972a, $b$; Westerhof 1977), overprinting the earlier metamorphic assemblages (Torres-Roldán 1981). This view is supported by a corresponding reversed metamorphic zonation in the Blanca Unit underlying the peridotite, which represents a metamorphic sole to the peridotite sheet developed during decompression from c. $8 \mathrm{kbar}$ to $3 \mathrm{kbar}$ (Tubía et al. 1997), and overprinting eclogites which cannot be directly related to peridotite emplacement on available evidence. This lower contact records a polyphase emplacement to shallow levels in the crust. However, the extreme thermal gradients $\left(143 \pm 20^{\circ} \mathrm{C} \mathrm{km}^{-1}\right)$ in the Carratraca section are mainly due to post-metamorphic, tectonic condensation (see Table 3). A geothermal gradient estimated from $P-T$ determinations for the latest metamorphism in the Jubrique Unit (from 7 to $15 \mathrm{~km}$ depth) is $38^{\circ} \mathrm{C} \mathrm{km}^{-1}$, not unreasonable for regional metamorphism. An emplaced sheet is unlikely to have caused such a thermal perturbation throughout an $8 \mathrm{~km}$ section.

Thermal modelling using a computer program, 1DT (Haugerud 1986) was employed to investigate the possible causes of the late orogenic thermal event in the Jubrique Unit. The program uses the Crank-Nicolson finite-difference method 
to solve the heat transfer equation in one dimension. The models were simplified to allow easy comparison of the effects of tectonic and thermal processes. For simplicity, a single-layer crust (density $(\rho)=2.85 \times 10^{-3} \mathrm{~kg} \mathrm{~m}^{-3}$, thermal diffusivity $(\kappa)=10^{-6} \mathrm{~m}^{2} \mathrm{~s}^{-1}$ ) with no radiogenic heat generation was used (this would actually tend to accentuate any thermal anomaly due to a peridotite sheet). Initial thermal gradients were linear, with modifications to simulate instantaneous emplacement of peridotite sheets (at 850 or $1100^{\circ} \mathrm{C}$ ) or removal of lithosphere at various depths. Temperature at the base of the model $(100 \mathrm{~km})$ was kept constant. Two styles of exhumation were modelled: uplift and erosion (1-10 $\mathrm{mm} \mathrm{a}^{-1}$ ) and horizontal extension (pure shear) at strain rates of $10^{-14}$ to $10^{-16} \mathrm{~s}^{-1}$. These give essentially identical results, producing near-isothermal decompression paths by rapid advection of geotherms towards the surface. These are modified slightly with the emplacement of a peridotite sheet $\left(10 \mathrm{~km}\right.$ thick at $1100^{\circ} \mathrm{C}$, Fig. 8) at depth, with a diachronous heating event similar to that seen in the Jubrique Unit. However, peak temperatures near the sheet predate exhumation, cooling is too rapid in the lower portions of the section, and the sheet still does not produce sufficient heat to sustain the high thermal gradients from 7 to $15 \mathrm{~km}$ in the crust. An additional heat source is needed to retard cooling further, and explain the annealing front within the peridotite sheet itself (Van der Wal \& Bodinier 1996).

Removal of part of the lower lithosphere was modelled as a simple truncation of an initial linear gradient by a region at $1200^{\circ} \mathrm{C}$ (Fig. 8). The $P-T$ paths resulting from extreme strain rates $\left(10^{-14} \mathrm{~s}^{-1}\right)$ during exhumation immediately following lithospheric removal approximate the Jubrique Unit paths well. Homogeneous thinning for $5 \mathrm{Ma}$ would bring the rocks into the upper $10 \mathrm{~km}$ of the crust, even in the absence of erosion. Cooling is retarded; there is a diachronous heating event, and the high thermal gradient is sustained at high crustal levels. An illustration of the limited importance of the peridotite sheet is that its addition to the model simply raises the temperatures of the rocks nearest to it transiently. This conclusion echoes the findings of Platt \& England (1994), who predicted a late- to post-tectonic, diachronous thermal event within the crust following removal of lithospheric material.

There are other possible candidates for a deep heat source (e.g. emplacement of a suite of large, mafic intrusions at the base of the crust, as has been suggested for the Pyrenees (Wickham \& Oxburgh 1987)), but the geophysical data increasingly support some form of lithospheric removal beneath the Alboran Basin during, or just prior to, the early Miocene. The seismicity under the Alboran Basin (Seber et al. 1996) suggests the presence of upwelled asthenosphere, which is represented by a region of anomalous, low-velocity, aseismic mantle. This is underlain by a region of high velocity and seismicity presumed to be delaminating lithosphere, but which could represent a detached portion not yet completely assimilated into the asthenospheric mantle. Mantle tomography (Blanco \& Spakman 1993) supports the presence of this submerged body of relatively rigid material, but it was interpreted by these authors to be a detached subduction slab; other authors have proposed subducted material on the strength of deep $(600 \mathrm{~km})$ earthquakes under the central Betics (Grimison \& Chen 1986; Buforn et al. 1988). The exact mechanism of lithospheric removal is much debated, ranging from convective removal (Platt \& Vissers 1989), to slab delamination/ detachment (de Jong 1991; Zeck et al. 1992; García-Dueñas et al. 1992; Docherty \& Banda 1995; Seber et al. 1996). An attractive hypothesis (Seber et al. 1996) is that a combination

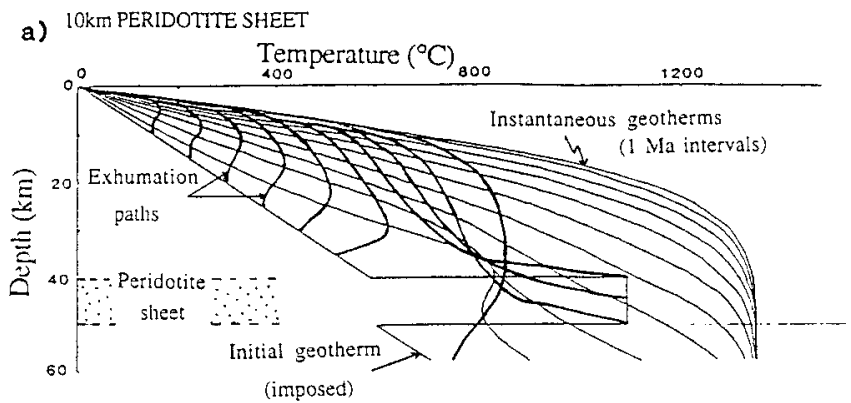

b) $10 \mathrm{~km}$ PERIDOTITE SHEET

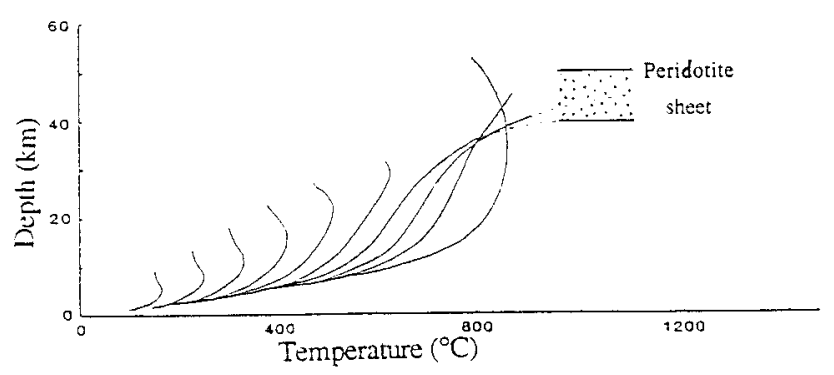

C) NO PERDOTITE SHEET

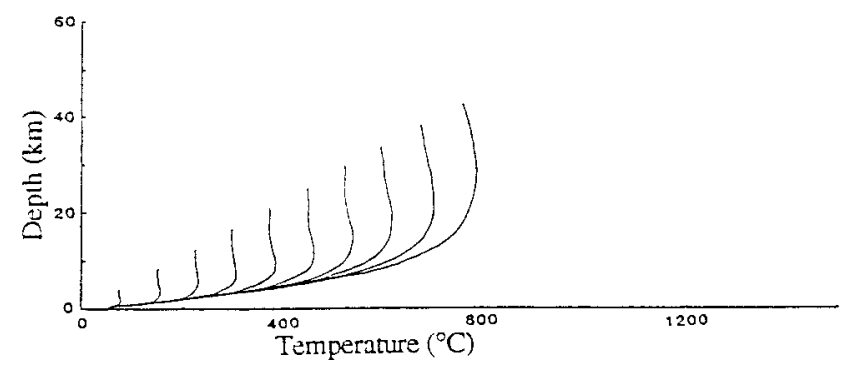

Fig. 8. (a) Temperature-depth plot showing evolution of geotherms (thin lines) in $1 \mathrm{Ma}$ increments from an initial value of $15^{\circ} \mathrm{km}^{-1}$ during homogeneous vertical thinning (strain rate $6.3 \times 10^{-15} \mathrm{~s}^{-1}$ ) following 'instantaneous' emplacement of a $10 \mathrm{~km}$ peridotite sheet at $1100^{\circ} \mathrm{C}$ (anomaly in initial geotherm, 40-50 km depth). Subvertical paths (thick lines) track uplift of rocks from a range of depths. (b) Temperature-depth paths for rocks in the above model with geotherms omitted. Note diachroneity of peak- $T$ conditions due to advection of heat during exhumation, and non-isothermal decompression of rocks initially at 30-40 km depth. (c) Temperature-depth paths from a model with no peridotite sheet, higher strain rate $\left(10^{-14} \mathrm{~s}^{-1}\right)$, and the same initial geotherm truncated at $50 \mathrm{~km}$ depth by 'asthenosphere' at $1200^{\circ} \mathrm{C}$, simulating removal of lower lithosphere material. Note the isothermal decompression paths due to greater retardation of cooling by the advected component of heat from the upwelled asthenosphere. This could represent the conditions during low-pressure metamorphism of the Jubrique Unit, unlike (b) above, demonstrating that the peridotite sheet contributes little to the broad thermal regime in the crust.

of processes acted on the lithosphere, for instance initial convective removal (Platt \& Vissers 1989) led to delamination, possibly in more than one direction (Seber et al. 1996). The interleaving of the peridotite sheet with crustal gneisses requires an element of simple shearing, as observed in the study area (Argles 1996) and the Sierra Alpujata (Tubía \& Cuevas 1986, 1987); the geological evidence in southern Spain suggests that emplacement closely followed lithospheric removal. 
Juxtaposition of peridotite with the Jubrique Unit gneisses across the shear zone caused heating of the crustal rocks while the thermal structure of the peridotite was 'frozen in'. Transient uplift and rapid tectonic exhumation followed immediately, with the advection of heat to high crustal levels, to produce the present geology.

This study has not directly addressed the question of timing of exhumation or metamorphism. Dates for the end of ductile deformation in the Internal Zones are $19 \mathrm{Ma}$ ( $\mathrm{Ar}-\mathrm{Ar}$ on micas related to pervasive ENE-directed shear) and 16-17 Ma (micas in shear zones) (Monié et al. 1991), while the peridotite emplacement is generally agreed to have occurred around $22 \mathrm{Ma}$ (Priem et al. 1979; Zindler et al. 1983). The earliest sediments attesting to exhumed peridotite are of AquitanianBurdigalian age (Serrano 1990; García-Dueñas et al. 1992; Sanz de Galdeano \& Vera 1992). This puts an upper limit of approximately $5 \mathrm{Ma}$ on the whole exhumation process; thermal modelling agrees with this (Fig. 8) in terms of the metamorphic field gradient in the Jubrique Unit, and is supported by the extreme attenuation of that crustal section.

\section{Conclusions}

A minimum fivefold vertical attenuation has been demonstrated for the Jubrique Unit overlying the Carratraca peridotite sheet. This attenuation was in part ductile, related to broadly coaxial extensional deformation which formed a flat-lying, hightemperature foliation and associated shear bands through most of the section. Brittle processes accounted for much of the condensation of the original metamorphic isograds, with NEdirected extensional fault zones excising parts of the section during predominately non-coaxial deformation and exhumation. Thermobarometric discontinuities imply the loss of at least $2 \mathrm{~km}$ of structural thickness across one fault zone.

A late- to post-tectonic thermal metamorphic event was associated with this rapid exhumation, overprinting previous prograde mineral assemblages and outlasting ductile deformation in some cases, particularly in the upper levels of the Jubrique Unit. Thermal modelling suggests that the emplacement of a hot peridotite sheet could not have caused such a substantial thermal anomaly without significant contributions from both rapid exhumation and asthenospheric upwelling. A regional tectonic scenario incorporating these processes would involve the catastrophic removal of material from the base of the lithosphere, either by delamination, convective removal, or a combination of the two. The thermal anomaly caused by the sudden upwelling of asthenospheric material to replace the removed lithospheric root would migrate rapidly to high levels because of the advective effect of tectonic exhumation. Indications are that lithospheric detachment led quickly to transient uplift, followed by crustal extension in the core of the orogen, exhumation, and orogenic collapse to below sea level, all within a few million years during the Early Miocene.

T.W.A. thanks P. C. England for advice on thermal modelling, and J. M. Tubía for discussions in the field. We are grateful to J. M. Tubía and J. Wheeler for thorough and constructive reviews. This research was conducted during tenure of NERC studentship GT4/92/242/G.

Appendix 1. Mineral analyses (oxide $w t \%$ )

\begin{tabular}{|c|c|c|c|c|c|c|c|c|c|c|}
\hline $\begin{array}{l}\text { Sample No. } \\
\text { Mineral analysis }\end{array}$ & $\mathrm{SiO}_{2}$ & $\mathrm{TiO}_{2}$ & $\mathrm{Al}_{2} \mathrm{O}_{3}$ & $\mathrm{FeO}^{\mathrm{T}}$ & $\mathrm{MnO}$ & $\mathrm{MgO}$ & $\mathrm{CaO}$ & $\mathrm{Na}_{2} \mathrm{O}$ & $\mathrm{K}_{2} \mathrm{O}$ & Total \\
\hline D154b Wm S2 & 45.59 & 0.28 & 34.77 & 2.52 & bd & 0.71 & 0.06 & 1.64 & 8.49 & 94.06 \\
\hline Chl S2 & 25.21 & 0.11 & 22.32 & 18.67 & 0.20 & 18.88 & bd & 0.02 & 0.06 & 85.47 \\
\hline P1 Syn-S2 & 60.25 & na & 24.51 & 0.22 & na & na & 6.35 & 7.68 & 0.31 & 99.32 \\
\hline Ep Syn-S2 & 37.93 & 0.24 & 23.94 & 11.26 & 0.11 & 0.04 & 22.73 & bd & 0.10 & 96.35 \\
\hline $\mathrm{D} 42 \mathrm{~b} \mathrm{Bt} \mathrm{S} 2$ & 35.93 & 2.63 & 19.51 & 16.93 & 0.15 & 9.80 & 0.03 & 0.05 & 9.56 & 94.59 \\
\hline St Syn-S2 & 27.42 & 0.43 & 55.02 & 12.09 & 0.32 & 1.19 & bd & 0.02 & 0.10 & 96.59 \\
\hline Pl Rim & 48.84 & na & 32.21 & 0.29 & na & na & 15.65 & 2.54 & 0.08 & 99.61 \\
\hline Wm S2 & 45.59 & 0.39 & 34.57 & 1.17 & 0.01 & 0.65 & 0.03 & 0.37 & 10.51 & 93.29 \\
\hline Chl S2 & 26.66 & 0.14 & 20.62 & 20.29 & 0.24 & 17.28 & 0.07 & bd & 0.34 & 85.54 \\
\hline D88ii Grt Core & 37.84 & 0.16 & 20.81 & 26.78 & 8.50 & 1.61 & 5.87 & na & na & 101.57 \\
\hline Grt Rim & 38.24 & 0.10 & 20.96 & 30.27 & 4.84 & 2.01 & 5.22 & na & na & 101.64 \\
\hline Bt S3 & 35.17 & 1.72 & 19.96 & 20.74 & 0.13 & 8.54 & 0.03 & 0.31 & 8.54 & 95.14 \\
\hline Bt Shear bands & 33.92 & 1.48 & 19.84 & 20.76 & 0.19 & 8.93 & 0.04 & 0.16 & 7.80 & 93.12 \\
\hline P1 Syn-S3 & 58.55 & na & 26.11 & 0.07 & na & na & 7.80 & 6.72 & 0.47 & 99.72 \\
\hline Wm S3 & 46.37 & 0.41 & 34.91 & 1.08 & 0.03 & 0.59 & 0.01 & 0.70 & 9.17 & 93.27 \\
\hline St Rim & 27.67 & 0.48 & 53.44 & 13.28 & 0.39 & 1.31 & 0.01 & 0.02 & 0.04 & 96.64 \\
\hline D88i Grt Core & 37.68 & 0.07 & 20.75 & 34.14 & 4.47 & 2.28 & 1.86 & na & na & 101.25 \\
\hline Grt Rim & 37.54 & 0.03 & 20.66 & 35.56 & 3.20 & 2.57 & 1.43 & na & na & 100.99 \\
\hline Bt S3 & 34.84 & 2.75 & 19.67 & 21.73 & 0.20 & 6.57 & na & 0.26 & 9.49 & 95.51 \\
\hline Pl Rim & 64.62 & na & 21.75 & bd & na & na & 3.52 & 9.24 & 0.67 & 99.80 \\
\hline Wm S3 & 46.61 & 0.62 & 34.96 & 1.08 & 0.04 & 0.61 & bd & 0.58 & 10.59 & 95.09 \\
\hline St S2-S3 & 27.38 & 0.68 & 53.57 & 13.52 & 0.44 & 1.19 & bd & bd & 0.02 & 96.80 \\
\hline E11 Bt S3 & 34.36 & 5.02 & 18.50 & 23.29 & 0.13 & 5.10 & bd & 0.17 & 9.35 & 95.92 \\
\hline Crd Matrix & 48.00 & bd & 31.49 & 12.16 & 0.42 & 5.62 & 0.04 & 0.18 & 0.04 & 97.95 \\
\hline Kfs Matrix & 65.20 & na & 17.98 & 0.03 & na & na & 0.07 & 1.49 & 14.29 & 99.06 \\
\hline Pl Matrix & 58.08 & na & 25.73 & 0.04 & na & na & 8.53 & 6.57 & 0.16 & 99.11 \\
\hline C234 Grt Core & 39.46 & 0.13 & 21.95 & 22.46 & 0.63 & 7.72 & 8.61 & na & na & 100.96 \\
\hline Grt Rim & 38.80 & 0.05 & 22.15 & 28.19 & 1.07 & 6.36 & 4.35 & na & na & 101.17 \\
\hline Cpx Core & 49.03 & 0.64 & 6.94 & 8.04 & 0.12 & 12.15 & 21.18 & 0.43 & 0.06 & 98.59 \\
\hline Pl Symplectite & 46.22 & na & 33.83 & 0.14 & na & na & 17.02 & 1.56 & 0.05 & 98.82 \\
\hline
\end{tabular}


Appendix 1. Continued

\begin{tabular}{lcccccccccc}
\hline $\begin{array}{l}\text { Sample No. } \\
\text { Mineral analysis }\end{array}$ & $\mathrm{SiO}_{2}$ & $\mathrm{TiO}_{2}$ & $\mathrm{Al}_{2} \mathrm{O}_{3}$ & $\mathrm{FeO}^{\mathrm{T}}$ & $\mathrm{MnO}$ & $\mathrm{MgO}$ & $\mathrm{CaO}$ & $\mathrm{Na}_{2} \mathrm{O}$ & $\mathrm{K}_{2} \mathrm{O}$ & Total \\
\hline Amph Rim Cpx & 44.49 & 1.86 & 10.75 & 10.96 & 0.11 & 13.39 & 11.91 & 1.55 & 1.04 & 96.06 \\
Opx Symplectite & 51.66 & 0.10 & 0.50 & 28.86 & 0.64 & 17.38 & 0.87 & 0.04 & 0.04 & 100.09 \\
Tit Incl. in Cpx & 30.05 & 36.52 & 2.52 & 0.57 & 0.10 & 0.09 & 28.08 & bd & 0.03 & 97.96 \\
Ilm After Tit & bd & 53.27 & 0.05 & 44.99 & 0.51 & 1.43 & na & na & na & 100.25 \\
B203 Grt Core & 39.90 & 0.05 & 22.36 & 21.87 & 0.37 & 13.39 & 1.28 & na & na & 99.22 \\
Pl in Grt core & 55.45 & na & 27.53 & 0.43 & na & na & 10.06 & 5.44 & 0.22 & 99.13 \\
Bt in Grt core & 38.42 & 0.83 & 18.47 & 8.03 & bd & 20.32 & 0.04 & 0.26 & 8.84 & 95.21 \\
Grt Plateau & 39.06 & 0.07 & 22.20 & 26.44 & 0.47 & 8.06 & 4.60 & na & na & 100.72 \\
Bt Matrix & 36.42 & 5.50 & 15.69 & 18.79 & 0.04 & 10.82 & bd & 0.13 & 9.13 & 96.52 \\
Pl Matrix & 56.45 & na & 27.21 & 0.04 & na & na & 9.27 & 5.88 & 0.20 & 99.05 \\
Kfs Matrix & 65.54 & na & 18.63 & 0.01 & na & na & 0.18 & 2.00 & 13.15 & 99.51 \\
Grt Rim & 38.45 & 0.05 & 21.31 & 31.00 & 1.23 & 4.64 & 4.45 & na & na & 101.13 \\
$\quad$ Crd Corona & 49.00 & 0.02 & 32.96 & 7.66 & 0.11 & 9.18 & 0.04 & 0.14 & 0.04 & 99.15 \\
Spl After Sil & 0.81 & 0.07 & 59.63 & 3.59 & 0.16 & 5.75 & na & na & na & $100.75^{*}$ \\
Pl After Sil & 46.93 & na & 33.27 & 0.49 & na & na & 16.85 & 1.71 & 0.13 & 99.38 \\
Grt Rim in Myl. & 38.78 & 0.07 & 21.72 & 27.84 & 1.38 & 5.54 & 5.83 & na & na & 101.16 \\
Crd in Myl. & 49.64 & 0.02 & 32.65 & 7.10 & 0.18 & 9.34 & 0.03 & 0.12 & 0.05 & 100.01 \\
Opx in Myl. & 50.91 & 0.09 & 1.78 & 28.90 & 0.58 & 17.57 & 0.18 & na & na & 100.01 \\
Bt in Myl. & 36.57 & 4.26 & 15.60 & 17.40 & 0.08 & 12.28 & bd & 0.14 & 8.92 & 95.25 \\
& & & & & & & & & &
\end{tabular}

$\mathrm{FeO}^{\mathrm{T}}$, all $\mathrm{Fe}\left(\mathrm{Fe}^{2}+\mathrm{Fe}^{3}\right)$; na, not analysed; bd, below detection.

*Includes $0.13 \% \mathrm{Cr}_{2} \mathrm{O}_{3}, 0.62 \% \mathrm{ZnO}$.

\section{References}

Argles, T.W. 1996. Tectonometamorphic studies in the crustal envelope of mantle peridotites in the western Betic Cordillera, Southern Spain. Doctoral Thesis, Oxford.

Azañon, J.M. \& GoFFÉ, B. 1997. Ferro and magnesiocarpholite assemblages as record of the high-pressure, low-temperature metamorphism in the central Alpujarrides, Betic Cordillera (SE Spain). European Journal of Mineralogy, 9, 1035-1051.

Bakker, H.E., De Jong, K., Helmers, H. \& Biermann, C. 1989. The geodynamic evolution of the internal zone of the Betic Cordilleras (south-east Spain): a model based on structural analysis and geothermobarometry. Journal of Metamorphic Geology, 7, 359-381.

Balanyá, J.C. 1991. Estructural del dominio de Alboran en la parte norte del Arco de Gibraltar. Doctoral Thesis, Granada.

—, Azañon, J.M., Sanchez-Gomez, M. \& García-Dueñas, V. 1993. Pervasive ductile extension, isothermal decompression and thinning of the Jubrique unit at the Paleogene times (Alpujarride complex, Western Betics). Comptes Rendus de l'Academie des Sciences, Paris, 316, 1595-1601.

Bhattacharya, A., Mohanty, L., Maji, A., Sen, S.K. \& Raith, M. 1992. Non-ideal mixing in the phlogopite-annite boundary: constraints from experimental data on $\mathrm{Fe}-\mathrm{Mg}$ partitioning and a reformulation of the biotite-garnet geothermometer. Contributions to Mineralogy and Petrology, 111, 87-93.

Blanco, M.J. \& Spakman, W. 1993. The P-wave velocity structure of the mantle below the Iberian Peninsula: Evidence for the subducted lithosphere below southern Spain. Tectonophysics, 221, 13-34.

Bohlen, S.R., Wall, V.J. \& Boettcher, A.L. 1983. Experimental investigations and geological applications of equilibria in the system $\mathrm{FeO}-\mathrm{TiO}_{2}-\mathrm{Al}_{2} \mathrm{O}_{3}-$ $\mathrm{SiO}_{2}-\mathrm{H}_{2} \mathrm{O}$. American Mineralogist, 68, 1049-1058.

Buforn, E., Udias, A. \& Mezcua, J. 1988. Seismicity and focal mechanisms in south Spain. Bulletin of the Seismological Society of America, 78, 20082024.

CESARE, B. 1994. Synmetamorphic veining: origin of andalusite-bearing veins in the Vedrette di Ries contact aureole, Eastern Alps, Italy. Journal of Metamorphic Geology, 12, 643-653.

Channel, J.E.T. \& Mareschal, J.C. 1989. Delamination and asymmetric lithospheric thickening in the development of the Tyrrhenian Rift. In: Coward, M.P., Dietrich, D. \& PARK, R.G. (eds) Alpine Tectonics. Geological Society, London, Special Publications, 45, 285-300.

Comas, M.C., García-Dueñas, V. \& Jorado, M.J. 1992. Neogene tectonic evolution of the Alboran Basin from MCS data. Geomarine Letters, 12, 157-164.

Darot, M. 1974. Cinématique de l'éxtrusion, a partir du manteau, des peridotites de la Sierra Bermeja (Serrania de Ronda, Espagne). Comptes Rendus de l'Academie des Sciences, Paris, 278 (Serie D), 1673-1676.

DE JoNG, K. 1991. Tectono-metamorphic studies and radiometric dating in the Betic Cordilleras SE Spain). Doctoral Thesis, Utrecht.
De Roever, W.P. \& Nijhuis, H.J. 1964. Plurifacial alpine metamorphism in the eastern Betic Cordilleras (SE Spain), with special reference to the genesis of glaucophane. Geologische Rundschau, 53, 324-336.

Dewey, J.F. 1988. Extensional collapse of orogens. Tectonics, 7, 1123-1140.

—, Helman, M.L., Turco, E., Hutton, D.H.W. \& Knott, S.D. 1989 Kinematics of the western Mediterranean. In: CowArD, M.P., DieTrich, D. \& PARK, R.G. (eds) Alpine Tectonics. Geological Society, London, Special Publications, 45, 265-283.

Dickey, J.S. 1970. Partial fusion products in Alpine-type peridotites: Serrania de Ronda and other examples. Mineralogical Society of America Special Publications, 3, 33-49.

Doblas, M. \& Oyarzun, R. 1989. "Mantle core complexes" and Neogene extensional detachment tectonics in the western Betic Cordilleras, Spain: an alternative model for the emplacement of the Ronda peridotite. Earth and Planetary Science Letters, 93, 76-84.

Docherty, C. \& BANDA, E. 1995. Evidence for the eastward migration of the Alboran Sea based on regional subsidence analysis: A case for basin formation by delamination of the subcrustal lithosphere? Tectonics, 14(4), 804-818.

England, P.C. \& Houseman, G.A. 1989. Extension during continental convergence, with application to the Tibetan Plateau. Journal of Geophysical Research, 94, 17 561-17 579.

García-Dueñas, V., Balanyá, J.C. \& Martínez-Martínez, J.M. 1992. Miocene extensional detachments in the outcropping basement of the Northern Alboran Basin (Betics) and their tectonic implications. Geomarine Letters, 12, 88-95.

Goffé, B., Michard, A., García-Dueñas, V., Gonzalez-Lodeiro, F., Monié, P., Campos, P., Galindo Zaldivar, F., Jabaloy, A., Martinez, J.M. \& SimanCas, J.F. 1989. First evidence of high-pressure metamorphism in the Alpujarride nappes, Betic Cordilleras (SE Spain). European Journal of Mineralogy, 1, 139-142.

Gomez-Pugnaire, M.T. \& Fernandez-Soler, J.M. 1987. High-pressure metamorphism in metabasites from the Betic Cordilleras and its evolution during the Alpine Orogeny. Contributions to Mineralogy and Petrology, 95, 231-244.

Grimison, N.L. \& CHEN, W.P. 1986. The Azores-Gibraltar plate boundary: focal mechanisms, depths of earthquakes, and their tectonic implications. Journal of Geophysical Research, 91, 2029-2047.

HAUGERUD, R.A. 1986. 1DT; an interactive, screen-oriented microcomputer program for 1-dimensional geothermal histories. US Geological Survey, Open File Report No. 86-0511.

Holland, T.J.B. 1993. Ax-A program to recalculate mineral analyses and derive activities. (Unpublished.)

\& Blundy, J. 1994. Non-ideal interactions in calcic amphiboles and their bearing on amphibole-plagioclase thermometry. Contributions to Mineralogy and Petrology, 116, 433-447. 
— \& Powell, R. 1990. An enlarged and updated internally consistent thermodynamic dataset with uncertainties and correlations: the system $\mathrm{K}_{2} \mathrm{O}-\mathrm{Na}_{2} \mathrm{O}-\mathrm{CaO}-\mathrm{MgO}-\mathrm{MnO}-\mathrm{FeO}-\mathrm{Fe}_{2} \mathrm{O}_{3}-\mathrm{Al}_{2} \mathrm{O}_{3}-\mathrm{TiO}_{2}-\mathrm{SiO}_{2}-\mathrm{C}-\mathrm{H}_{2}-\mathrm{O}_{2}$. Journal of Metamorphic Geology, 8, 89-124.

Houseman, G.A. 1996. From mountains to basin. Nature, 379, 771-772.

KePpler, H. 1989. The influence of the fluid phase composition on the solidus temperatures in the haplogranite system $\mathrm{NaAlSi}_{3} \mathrm{O}_{8}-\mathrm{KAlSi}_{3} \mathrm{O}_{8}-\mathrm{SiO}_{2}$ $\mathrm{H}_{2} \mathrm{O}-\mathrm{CO}_{2}$. Contributions to Mineralogy and Petrology, 102, 321-327.

Kerrick, D.M. 1990. The $\mathrm{Al}_{2} \mathrm{SiO}_{5}$ Polymorphs. Mineralogical Society of America.

Kornprobst, J. 1974. Contribution à l'étude pétrographique et structurale de la zone interne du Rif (Maroc Septentrional). Notes et Mémoires du Service Géologique du Maroc, 251, 256.

Kretz, P. 1983. Symbols for rock-forming minerals. American Mineralogist, 68, 277-279.

Lonergan, L. 1993. Timing and kinematics of deformation in the Malaguide Complex, Internal Zone of the Betic Cordillera, Southeast Spain. Tectonics, 12, 460-476.

— \& PlatT, J.P. 1995. The Malaguide-Alpujarride boundary: a major extensional contact in the Internal Zone of the eastern Betic Cordillera, SE Spain. Journal of Structural Geology, 17, 1655-1671.

Loomis, T.P. 1972a. Contact metamorphism of pelitic rock by the Ronda ultramafic intrusion, southern Spain. Geological Society of America Bulletin, 83, 2449-2474.

1972b. Diapiric emplacement of the Ronda high-temperature intrusion, southern Spain. Geological Society of America Bulletin, 83, 2475-2496.

Lundeen, M.T. 1978. Emplacement of the Ronda Peridotite, Sierra Bermeja, Spain. Geological Society of America Bulletin, 89, 172-180.

Massonne, H.J. \& Schreyer, W. 1987. Phengite geobarometry based on the limiting assemblage with K-feldspar, phlogopite, and quartz. Contributions to Mineralogy and Petrology, 96, 212-224.

Monié, P., Galindo-Zaldivar, J., Gonzalez-Lodeiro, F., Goffé, B. \& JABALOY, A. 1991. ${ }^{40} \mathrm{Ar} /{ }^{39} \mathrm{Ar}$ geochronology of Alpine tectonism in the Betic Cordilleras (southern Spain). Journal of the Geological Society, London, 148, 289-297.

Morley, C.K. 1993. Discussion of origins of hinterland basins to the Rif-Betic Cordillera and Carpathians. Tectonophysics, 226, 359-376.

Mukhopadhyay, A., Bhattacharya, A. \& Mohanty, L. 1992. Geobarometers involving clinopyroxene, garnet, plagioclase, ilmenite, rutile, sphene and quartz: estimation of pressure in quartz-absent assemblages. Contributions to Mineralogy and Petrology, 110, 346-354.

Oвата, M. 1980. The Ronda Peridotite: garnet, spinel, and plagioclase lherzolite facies and the $\mathrm{P}-\mathrm{T}$ trajectories of a high-temperature mantle intrusion. Journal of Petrology, 21, 533-572.

PAttison, D.R.M. \& Newton, R.C. 1989. Reversed experimental calibration of the garnet-clinopyroxene $\mathrm{Fe}-\mathrm{Mg}$ exchange thermometer. Contributions to Mineralogy and Petrology, 101, 87-103.

Philpotts, A.R. 1964. Origin of Pseudotachylite. American Journal of Science, 262, 1008-1035.

Platt, J.P. \& England, P.C. 1994. Convective removal of lithosphere beneath mountain belts: thermal and mechanical consequences. American Journal of Science, 294(3), 307-336.

\& VisSERS, R.L.M. 1989. Extensional collapse of thickened continental lithosphere: a working hypothesis for the Alboran Sea and the Gibraltar arc. Geology, 17, 540-543.

Powell, R. \& Holland, T.J.B. 1988. An internally consistent thermodyamic dataset with uncertainties and correlations: 3. Applications to geobarometry, worked examples, and a computer program. Journal of Metamorphic Geology, 6, 173-204.

Priem, H.N.A.K., Hebeda, E. H., Boelrijk, N.A.I.M., Verdumen, T.E.A. \& OEN, I.S. 1979. Isotopic dating of the emplacement of the ultramafic masses in the Serrania de Ronda, Southern Spain. Contributions to Mineralogy and Petrology, 70, 103-109.

ROYDEN, L.H. 1993. Evolution of retreating subduction boundaries formed during continental collision. Tectonics, 12, 629-638.

Sanz de Galdeano, C. \& Vera, J.A. 1992. Stratigraphic record and palaeogeographical context of the Neogene basins in the Betic Cordillera, Spain. Basin Research, 4, 21-36.

Seber, D., Barazangi, M., Ibenbrahim, A. \& Demnati, A. 1996. Geophysical evidence for lithospheric delamination beneath the Alboran Sea and Rif-Betic mountains. Nature, 379, 785-790.
Serrano, F. 1990. El Mioceno medio en el área de Nijar (Almería, España). Revistas de la Sociedad Geologica de España, 3, 65-78.

SibSON, R.H. 1975. Generation of pseudotachylyte by ancient seismic faulting. Royal Astronomical Society Geophysical Journal, 43, 775-794.

Soto, J.I. \& Gervilla, F. 1991. Los macizos ultramáficos de Sierra de las Aguas y Sierra de la Robla como una ventana extensional (Béticas occidentales). Geogaceta, 9, 21-23.

Spear, F.S. \& Cheney, J.T. 1989. A petrogenetic grid for pelitic schists in the system $\mathrm{SiO}_{2}-\mathrm{Al}_{2} \mathrm{O}_{3}-\mathrm{FeO}-\mathrm{MgO}-\mathrm{K}_{2} \mathrm{O}-\mathrm{H}_{2} \mathrm{O}$. Contributions to Mineralogy and Petrology, 101, 149-164.

Torné, M. \& BAnda, E. 1992. Crustal thinning from the Betic Cordillera to the Alboran Sea. Geomarine Letters, 12, 76-81.

- Banda, E., García-Dueñas, V. \& Balanyá, J.C. 1992. Mantle-lithospere bodies in the Alboran crustal domain (Ronda peridotites, Betic-Rif orogenic belt). Earth and Planetary Science Letters, 110, 163-171.

TORRES-RoldÁN, R.L. 1981. Plurifacial metamorphic evolution of the Sierra Bermeja aureole (Southern Spain). Estudios Geologicos, 37, 115-133.

TubíA, J.M. 1994. The Ronda peridotites (Los Reales nappe): an example of the relationship between lithospheric thickening by oblique tectonics and late extensional deformation within the Betic Cordillera (Spain). Tectonophysics, 238, 381-398.

_ \& Cuevas, J. 1986. High-temperature emplacement of the Los Reales Peridotite nappe (Betic Cordillera, Spain). Journal of Structural Geology, 8, 473-482.

_ \& 1987. Structures et cinematiques liees a la mise en place des peridotites de Ronda (Cordilleres Betiques, Espagne). Geodynimica Acta, 1, 59-69.

— \& Gil Ibarguchi, J.L. 1991. Eclogites of the Ojen nappe: a record of subduction in the Alpujarride complex (Betic Cordilleras, southern Spain). Journal of the Geological Society, London, 148, 801-804.

— Cuevas, J. \& Gil Ibarguchi, J.I. 1997. Sequential development of the metamorphic aureole beneath the Ronda peridotites and its bearing on the tectonic evolution of the Betic Cordillera. Tectonophysics, 279, 227-252.

VAN DeR WAL, D. 1993. Deformation processes in Mantle Peridotites. Doctoral Thesis, Utrecht.

VAN DER WAL, D. \& BODINIER, J.L. 1996. Origin of the recrystallization front in the Ronda Peridotite by km-scale pervasive porous melt flow. Contributions to Mineralogy and Petrology, 122, 387-405.

van Wees, J.D., De Jong, K. \& Cloetingh, S. 1992. Two-dimensional P-T-t modelling and the dynamics of extension and inversion in the Betic Zone (SE Spain). Tectonophysics, 203, 305-324

Vissers, R.L.M., Platt, J.P. \& VAN Der WaL, D. 1995. Late orogenic extension of the Betic Cordillera and the Alboran Domain: A lithospheric view. Tectonics, 14, 786-803.

WATERS, D.J. 1991. Hercynite-quartz granulites: phase relations, and implications for crustal processes. European Journal of Mineralogy, 3, 367-386.

Watts, A.B., Platt, J.P. \& Buhl, P. 1993. Tectonic evolution of the Alboran Sea basin. Basin Research, 5, 153-77.

Wenner, D.B. \& TAYLOR, H.P. 1971. Temperatures of serpentinization of ultramafic rocks based on ${ }^{18} \mathrm{O} /{ }^{16} \mathrm{O}$ fractionation between coexisting serpentine and magnetite. Contributions to Mineralogy and Petrology, 32, 165-185.

Westerhof, A.B. 1977. Contact relations of high-T Peridotites in the Serrania de Ronda, Southern Spain. Tectonophysics, 39, 579-591.

Wickham, S.M. \& OxbuRGH, E.R. 1987. Low pressure regional metamorphism in the Pyrenees and its implications for the thermal evolution of rifted continental crust. Philosophical Transactions of the Royal Society of London, 321, 219-242.

Wortel, M.J.R. \& Spakman, W. 1992. Structure and dynamics of subducted lithosphere in the Mediterranean region. Proceedings Koninklijk Nederlands Akadamie Wetenschap, 95, 325-347.

Xu, G., Will, T.M. \& Powell, R. 1994. A calculated petrogenetic grid for the system $\mathrm{K}_{2} \mathrm{O}-\mathrm{FeO}-\mathrm{MgO}-\mathrm{Al}_{2} \mathrm{O}_{3}-\mathrm{SiO}_{2}-\mathrm{H}_{2} \mathrm{O}$, with particular reference to contact-metamorphosed pelites. Journal of Metamorphic Geology, 12, 99-119.

YardLEY, B.W.D. 1977. An empirical study of diffusion in garnet. American Mineralogist, 62, 793-800.

Zeck, H.P., Monié, P., Villa, I.M. \& Hansen, B.T. 1992. Very high rates of cooling and uplift in the Alpine belt of the Betic Cordilleras, southern Spain. Geology, 20, 79-82.

Zindler, A., Staudigel, H., Hart, S.R., Endres, R. \& Goldstein, S. 1983. Nd and $\mathrm{Sr}$ isotopic study of a mafic layer from the Ronda ultramafic complex. Nature, 304, 226-230. 